Article

\title{
Greening Energy Finance of Multilateral Development Banks: Review of the World Bank's Energy Project Investment (1985-2019)
}

\author{
Jeong Won $\mathrm{Kim}^{1}$ and Jae-Seung Lee ${ }^{2, *}$ \\ 1 Energy Studies Institute, National University of Singapore, Singapore 119620, Singapore; esikjw@nus.edu.sg \\ 2 Division of International Studies and Graduate School of Energy and Environment, Korea University, \\ Seoul 02841, Korea \\ * Correspondence: jaselee@korea.ac.kr; Tel.: +82-3290-2419
}

Citation: Kim, J.W.; Lee, J.-S. Greening Energy Finance of Multilateral Development Banks: Review of the World Bank's Energy Project Investment (1985-2019). Energies 2021, 14, 2648. https:/ / doi.org/10.3390/en14092648

Academic Editors: Abbas Mardani and Claudiu Albulescu

Received: 23 February 2021

Accepted: 22 April 2021

Published: 5 May 2021

Publisher's Note: MDPI stays neutral with regard to jurisdictional claims in published maps and institutional affiliations.

Copyright: (C) 2021 by the authors Licensee MDPI, Basel, Switzerland. This article is an open access article distributed under the terms and conditions of the Creative Commons Attribution (CC BY) license (https:/ / creativecommons.org/licenses/by/ $4.0 /)$.

\begin{abstract}
To effectively mitigate global greenhouse gas emissions, both industrialized and developing countries should participate in the energy transition that to replace fossil fuels with renewable energy. Multilateral development banks (MDBs) have been scaling up their renewable energy finance to developing countries to help them achieve their renewable energy targets. This study examines the evolution of energy financing of the World Bank, the oldest and largest MDB, by reviewing and estimating its sector-specific energy investments made over the last 35 years (1985-2019). The results confirm that the World Bank is on the right track supporting energy transition in developing countries, overall; however, limitations exist. While the share of investments in non-hydro renewable energy (NHRE) in the World Bank's total energy finance was expanded from 1\% (1985-1990) to $16.5 \%$ (2011-2019), the share of fossil fuels contracted from $51.8 \%$ (1985-1990) to $15.2 \%$ (2011-2019). However, commitments to fossil fuels have been sustained, but financing for NHRE-US $\$ 1.2$ billion per year after the adoption of the Paris Agreement-is still insufficient to meet demand. Moreover, NHRE finance tended to be concentrated in middle-income developing countries. To accelerate the energy transition in developing countries, the World Bank needs to increase NHRE finance with more support for low-income countries while reducing fossil fuel finance.
\end{abstract}

Keywords: energy finance; renewable energy investment; multilateral development bank; World Bank; energy transition

\section{Introduction}

Given that energy consumption represents the largest source of global greenhouse gas (GHG) emissions-approximately 73\% of total emissions in 2016 [1], promoting the energy transition from fossil fuels to renewable energy is considered critical to tackling global climate change [2,3]. Led by many developed countries, such as the United States, Japan, and European countries, global annual investment in renewable energy increased from US\$70 billion in 2005 to US $\$ 288.3$ billion in 2018, peaking at US\$325 billion in 2017 [4]. Renewable generation investment has also exceeded fossil fuel generation investment since $2015[5,6]$. In consequence, the global renewable energy capacity more than quadrupled in the last decade, from 354 gigawatts (GW) in 2009 to 1449 GW in 2018 [4].

Unquestionably, decarbonizing the energy system in industrialized countries that release large amounts of GHGs is fundamental to reducing global GHG emissions. Nevertheless, developing countries also need to take part in accelerating this transition towards low-carbon renewable energy because their fast-growing populations and economies will produce more and more GHG emissions [7]. Six developing countries, including China and India, were listed in the top 10 GHG emitters in 2016 [1]. Furthermore, the International Energy Agency (IEA) (2019) forecasted that the respective oil demand in Africa and India between 2018 and 2040 would surpass China's oil demand [8], which implies that many 
developing countries will become major GHG emitters in the near future if they do not make mitigation efforts. Using renewable energy enables developing countries to produce fewer GHG emissions and improve energy security by reducing their dependence on imported, expensive fossil fuels $[9,10]$. Due to these benefits, many developing countries have expressed their willingness to expand renewable energy generation capacity in their nationally determined contributions (NDCs) and national energy plans.

However, energy transition in developing countries remains challenging because of a lack of finance, technology, and human resources $[9,11,12]$. The biggest challenge is that the energy transition requires enormous investment. For instance, it is estimated that at least US $\$ 241$ billion would be needed for 28 African countries pledging to unconditional carbon mitigation targets in their NDCs, to meet their renewable energy targets [13]. While renewable energy requires much larger upfront capital investment than fossil fuel-based power systems $[14,15]$, developing countries' national budgets are often too limited to fund various renewable energy projects $[3,9,16]$. In emerging economies, aggressive increase in private investment has contributed to supporting renewable energy projects [4-6]. However, low-income developing countries often face barriers that obstruct private investment, such as small and immature capital markets and poor infrastructure and institutional frameworks [11,15]. For these reasons, low-income developing countries have claimed that external financial and technical assistance is indispensable to achieving their renewable energy targets $[17,18]$, and they have heavily depended on international development finance to facilitate renewable energy projects $[9,11,12,19]$.

In response to meeting their needs, international society has resolved to scale up climate finance to support developing countries' efforts to combat climate change, including promoting renewable energy, with a series of agreements and accords under the United Nations Framework Convention on Climate Change (UNFCCC), such as the Kyoto Protocol (1997), Copenhagen Accord (2009), Cancún Agreements (2010), and the Paris Agreement (2015) [20-22]. As a result, international financial support for renewable energy has expanded significantly over the last few decades. Official development assistance (ODA) for the renewable energy sector increased by an average of $20 \%$ per year between 2000 and 2013 [17]. An increasing amount of money has been invested in off-grid solutions based on renewable energy and capacity building projects in developing countries [9].

Along with various bilateral and multilateral institutions, multilateral development banks (MDBs) are central players in global renewable energy financing [2,3,23-25]. As concerns about climate change and sustainable development have grown, MDBs have prioritized supporting energy efficiency and renewable energy technologies since the 2000s $[2,25,26]$. The finance of MDBs in renewable energy generation was US\$114 million in 2002 but increased to US $\$ 2150$ million in 2018 with a record high of US $\$ 3042$ million in 2016 [27]. However, despite their increasing interest in renewable energy, MDBs have also funded fossil fuel projects [2,22,28]. For successful energy transition, fossil fuels should be phased out while renewable energy should be expanded. If support for fossil fuels continues, it will slacken the pace of the energy transition even if renewable energy investment is scaled up.

Therefore, out interest is in not only an increase in the absolute amounts of renewable energy finance of MDBs but also a change in its share in energy finance over time, particularly relative to finance for fossil fuels. Hence, this study examines the evolution of energy financing of MDBs and assesses whether it is conducive to supporting the developing countries' transition towards a low-carbon economy. Several studies have reviewed the MDBs' energy finance. Despite providing useful information, but the scope of analysis, such as time frame and project type, was limited. They included out-of-date data $[3,20,26,29,30]$, covered a short time period $[2,26,28]$, or focused on limited types of projects $[25,26,30]$, which makes it difficult to observe both long-term and recent trends in energy financing of MDBs (Table 1). To overcome these limitations, this study provides a more comprehensive mapping of MDBs' energy financing, based on the World Bank's energy-related projects approved during the last 35 years (1985-2019). The World Bank is the oldest and largest 
MDB and the biggest single multilateral source of energy projects [22,24,31], contributing approximately US $\$ 63$ billion in over 500 energy-related projects in more than 110 countries since 2010. As such, we expect that the World Bank may represent MDBs and provide insights into understanding the behavior of MDBs, although a review of one MDB may also have a limitation. Specifically, this study explores how the volumes of total and sector-specific energy finance of the World Bank have changed over time, who have been the primary recipients, and whether its interest has shifted from fossil fuels to renewable energy. Given that MDBs catalyze private investment in risky sectors by constructing norms and mitigating risks [23,32], tracking the World Bank's energy finance trends will elucidate the MDBs' priority in the energy sector and predict the future landscape of global energy finance.

Table 1. Overview of literature on energy financing of MDBs.

\begin{tabular}{cccc}
\hline Study & MDB & Time Frame & Project \\
\hline Barnes et al. (2010) [29] & World Bank & 9 years (2000-2008) & Energy access \\
Christianson et al. (2017) [2] & 3 MDBs ${ }^{1}$ & 2 years (2015-2016) & Energy supply \\
Delina (2011) [20] & Asian Development Bank & 12 years (1997-2008) & Energy sector \\
Delina (2017) [3] & Asian Development Bank & 15 years (2000-2014) & Energy sector \\
Martinot (2001) [26] & World Bank & 8 years (1992-1999) & Renewable energy \\
Razavi (1995) [30] & World Bank & 20 years (1975-1994) & Oil \& gas \\
Steffen \& Schmidt (2019) [25] & 10 MDBs ${ }^{2}$ & 10 years (2006-2015) & Power generation \\
Wright et al. (2017) [28] & 6 MDBs $^{3}$ & 3 years (2013-2015) & Climate \& fossil \\
\hline
\end{tabular}

\footnotetext{
${ }^{1}$ Asian Development Bank (ADB), International Finance Corporation (IFC), World Bank. ${ }^{2}$ ADB, African Development Bank (AfDB), Development Bank of Latin America (CAF), European Bank for Reconstruction and Development (EBRD), European Investment Bank (EIB), Inter-American Development Bank (IADB), IFC, Islamic Development Banks (IsDB), Multilateral Investment Guarantee Agency (MIGA), World Bank. ${ }^{3}$ ADB, AfDB, EBRD, EIB, IADB, World Bank.
}

The remainder of this paper is structured as follows: Section 2 describes MDBs' roles and commitment to international finance for renewable energy. Section 3 explains how to construct the dataset and estimate the financed amounts committed by the World Bank to energy-related activities. Section 4 answers the research questions by reviewing the the World Bank's energy finance trends between 1985 and 2019 in terms of total financed amounts, regional distribution, and sectoral allocation of investments. Section 5 discusses how MDBs can accelerate the energy transition in developing countries based on the review of the World Bank's commitments to fossil fuels and renewable energy. Finally, Section 6 concludes the paper with key findings and implications.

\section{Roles of MDBs in Renewable Energy Financing for Developing Countries}

Because of their fiscal constraints, most developing countries rely on external funding to deploy renewable energy besides their domestic finance. External funding generally comes from official development finance (ODF) and private sector investment. Because the vast investment required for energy transition cannot exclusively come from public entities, the participation of the private sector has been increasingly important to boost renewable energy financing and bridge the current investment gap. Indeed, private investment has increased over time and has made a significant contribution to promoting renewable energy in both developed and developing countries by reducing renewable generation costs and implementing various renewable projects [33].

Private investment has taken the lead in renewable energy finance globally during the last decade. For example, it accounted for $92 \%$ (US\$242 billion) of the total renewable energy financing made in 2016 [6] and reached US\$277 billion in 2018 [5]. Although most private investments are used for domestic projects [6], cross-border private investment for developing countries still exceeds the MDBs' investment (Figure 1). While the aggregate of renewable energy investment of eight major MDBs (ADB, AfDB, Asian Infrastructure Investment Bank, EBRD, EIB, IADB, IsDB, and the World Bank Group) was US $\$ 7.8$ billion per year between 2012 and 2019 [34-41], the cross-border private investment was 
US $\$ 18.6$ billion per year during the same period [42]. Moreover, the evident increasing trend suggests that cross-border private investment will continue to increase.

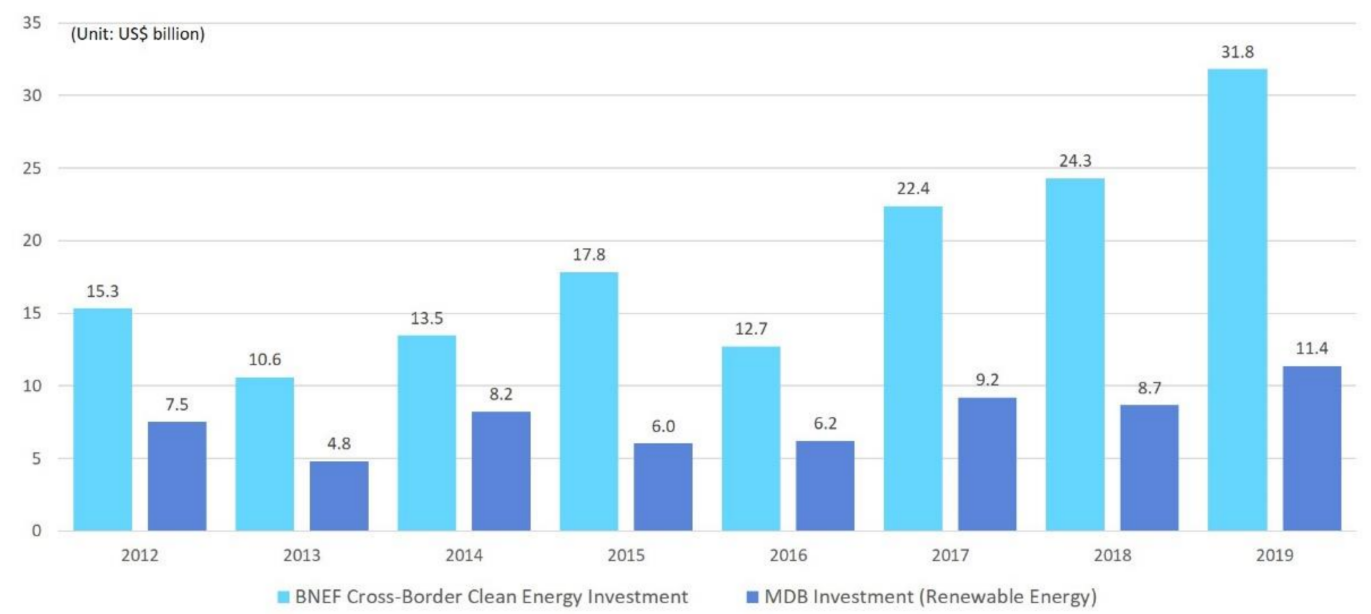

Figure 1. Cross-border private investment and MDBs' investment in renewable energy. Source: authors' illustration based on [34-42].

However, as shown in Figure 2, cross-border private investment tends to be allocated favorably to higher-income developing countries. Out of US $\$ 148.4$ billion invested by the private sector between 2012 and 2019, almost 70\% went to five countries: India (lower-middle-income), Brazil (upper-middle-income), Chile (high-income), Mexico (upper-middle-income), and Taiwan (high-income). Of the 27 countries receiving more than US $\$ 1$ billion, upper-middle-income countries represented the highest share (13 countries, $43.3 \%$ ), followed by lower-middle-income countries ( 8 countries, $26.7 \%$ ), high-income countries ( 5 countries, $16.7 \%$ ), and low-income countries ( 1 country, $3.3 \%)$. While private investment prevails in North America, Oceania, Western Europe, and East Asia [5], less than $10 \%$ of global private investment in renewable energy flowed into South Asia, SubSaharan Africa, Latin America, and the Caribbean between 2013 and 2016 [6]. In brief, many low-income countries still have difficulties attracting private finance to stimulate their renewable energy sector [33], and public finance remains a critical source of renewable energy investment in these countries [43].

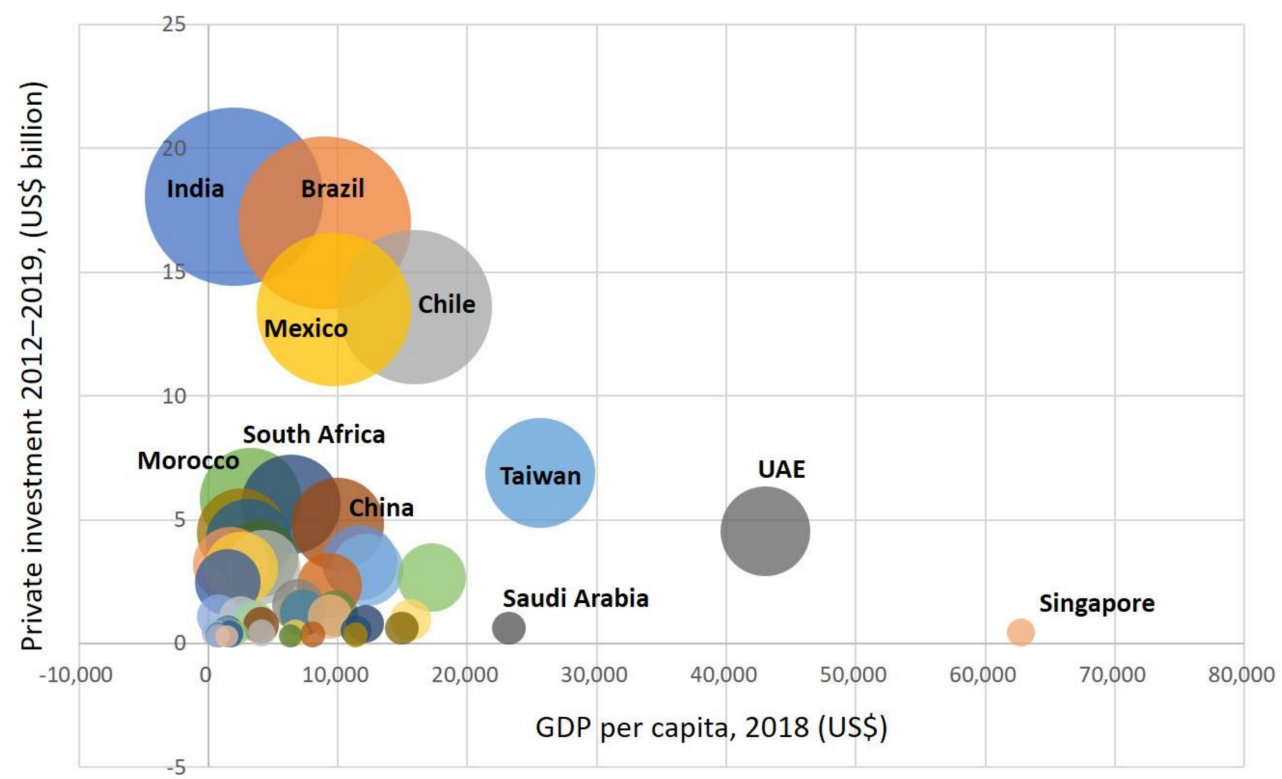

Figure 2. Allocation of cross-border private investment. Source: authors' illustration based on [42]. 
Private investors are sometimes reluctant to engage in renewable energy projects in low-income developing countries because of some risk factors, including political and regulatory risk, economic volatility, and insufficient grid and transmission links [44,45]. The private sector typically invests in bankable projects for the sake of a high rate of return. The profitability of renewable energy projects is highly affected by fossil fuel prices and favorable policies for renewable energy, such as subsidies and carbon taxes. If these conditions change frequently and are difficult to predict, it creates uncertainty about the results of renewable energy projects and reduces incentives for private financing [44,46]. For foreign direct investment (FDI), the private sector is particularly concerned with selecting recipient countries to minimize the uncertainty mentioned above. FDI is often associated with the enabling environment of a country, such as supportive legal and institutional frameworks, good infrastructure, and stable political and macroeconomic conditions. Since many developing countries do not meet these qualifications, they experience difficulty in attracting FDI $[9,11,20]$.

As a result, the ODF, including bilateral ODA and multilateral financial assistance, has been a significant source of renewable energy finance in most developing countries [9,11,12]. MDBs, international institutions that support the socioeconomic development of developing countries, are critical donors in ODF flow. They provide recipient countries with financial assistance in the form of grants and loans, technical assistance, and policy advice for capacity building $[2,32,47,48]$. Intending to redress global economic inequality, MDBs have a long history of constructing infrastructure that help economic vitalization and social development in developing countries $[2,48]$. Because development has an undetachable connection with energy, financing to improve energy access has been a core activity of MDBs [23,31]. Fossil fuels and hydropower generation have been the main sectors of MDBs' energy finance portfolio [26,30]. However, the emergence of climate change issues and the global commitment to tackling them drove MDBs to focus more on investment in renewable energy projects $[2,3,25]$. In several joint statements, MDBs pledged to raise their climate finance: for example, US $\$ 100$ billion by 2020 and US $\$ 175$ billion by 2025 [49,50]. In addition, the World Bank announced in 2017 that it would discontinue funding upstream oil and gas projects after 2019 to support achieving the global goal of limiting global temperature increase to well below $2{ }^{\circ} \mathrm{C}$ [51]. In fact, MDB investment in renewable energy has shown an increasing trend overall, despite some annual fluctuations. The aggregate investment of the eight major MDBs was US\$7.5 billion in 2012 and reached US\$11.4 billion in 2019 (Figure 1) [34-41].

In addition to the direct contribution to expanding energy infrastructure in developing countries, the MDBs' investment in renewable energy projects often functions as a strong driver of cross-border private investment [33]. It catalyzes the financing of other public and private sectors by mitigating the risks of renewable energy projects and creating an enabling environment $[2,45,47]$. One of the unique features of MDBs is that, unlike commercial banks, they do not seek to maximize return on investment, which allows them to invest in high-risk countries and sectors where private sector investment is rarely made [23,48]. MDBs often provide financial and technical assistance to policy reform and local capacity building programs to ease regulatory and governance problems in high-risk countries [2,23]. Through such policy dialogues with national and local governments, they can address investment risks and build a conducive business environment by introducing various financial de-risking instruments, including credit enhancement, guarantees, and political risk insurance $[45,47,52]$. They also mobilize private investments by communicating and working with private equity investors and local banks [53]. Moreover, MDBs can initiate projects in high-risk sectors by offering favorable lending terms, such as longer maturities and very low or no interest rates $[23,32,48]$. These proactive actions enable renewable energy projects in developing countries to become more feasible and attractive by creating a market and ensuring certainty and bankability of the projects [32]. 


\section{Data and Methods}

\subsection{Data and Scope of Analysis}

The analysis focuses on mapping the World Bank's energy financing for developing countries during the last 35 years, from 1985 to 2019. It includes pre and post periods of significant landmarks that have reinforced climate financing issues in the history of global climate change negotiations: before the UNFCCC (1985-1993) entered into force, under multiple decisions to raise funds for climate change, including the Kyoto Protocol, Copenhagen Accord, and Cancun Agreements (1994-2015), and after the adoption of the Paris Agreement (2016-2019). For the last three decades, international society has recognized the need for financial assistance for developing countries, stipulated the establishment of new climate funds, and urged governments and other international actors to scale up climate finance $[20,22]$. The broad time frame will enable us to identify long-term trends and changes in the World Bank's financial flows to the energy sector following international commitments to combat climate change.

The analysis is based on the World Bank's investment project data available on its website [54]. The database provides information on the source and volume of finance for projects approved by the World Bank's Board of Executive Directors. The database includes all projects financed by loans from the World Bank's two principal institutions: the International Bank for Reconstruction and Development (IBRD) for middle-income countries and International Development Association (IDA) for the world's poorest countries, and grants from the IDA and Financial Intermediary Funds (FIFs) of which the World Bank has trusteeship, such as the Global Environment Facility (GEF). However, it does not include investment from the other two private sector branches of the World Bank Group: IFC and MIGA.

\subsection{Methods for Energy Financing Review}

Because this study aims to identify the World Bank's energy financing trends over time by subsector, it is necessary to estimate the investment amount in each subsector. For this estimation, the total costs of each energy-related project are broken down into subsector-specific costs based on the project summary section and project documents, such as appraisal documents and result reports, uploaded to the World Bank's website [54]. The estimation methodology differentiates this study from other studies that do not clearly explain how to estimate energy finance. Most previous studies have calculated energy finance based on energy-related projects, but rarely describe how these projects had been defined and selected. They also did not specify whether they had used the total costs of each project or subsector-specific costs for their estimation. Many World Bank projects include multisector components, although they are classified into one sector. For example, some irrigation projects belong to the Water, Sanitation, and Waste sector since their main goal is to improve water supply, but they also include hydropower generation as one of the project components. If these projects are excluded from the estimation, the total energy finance will be underestimated. On the other hand, if these projects are included and their total costs are used, the total energy finance will be overestimated because it also includes finance for non-energy components. Therefore, it is critical to define how energy-related projects and relevant finance are extracted to estimate the total energy finance.

First, all active and closed projects related to energy were selected from the database. The projects in the database are categorized into 11 sectors: Agriculture; Education; Energy and Extractives; Financial Sector; Health; Industry and Trade; Information and Communication; Public Administration; Social Protection; Transportation; and Water, Sanitation, and Waste. Each sector has several subsectors. The Energy and Extractives sector is divided into eleven subsectors: Energy Transmission and Distribution; Mining; Non-Renewable Energy Generation; Oil and Gas; Other Energy and Extractives; Public Administration-Energy and Extractives; Renewable Energy Biomass; Renewable Energy Geothermal; Renewable Energy Hydro; Renewable Energy Solar; and Renewable Energy Wind. Each project belongs to a single or multiple subsectors, depending on the project components. The 
projects falling into the "Energy and Extractives" sector, except for the non-fossil fuel mining projects, were preferentially included in our analysis as they were designed to solve energy problems and improve energy infrastructure. Projects in the other sectors were also selected if they contain at least one subsector of the Energy and Extractives sector. In total, the dataset has 1541 projects: 1479 country-level projects and 62 regional projects in 143 countries (Table 2).

Table 2. Data composition by region.

\begin{tabular}{cccc}
\hline \multirow{2}{*}{ Region } & Number of Countries & \multicolumn{2}{c}{ Number of Projects } \\
\cline { 3 - 4 } & & Regional & Country-Level \\
\hline Sub-Saharan Africa & 48 & 51 & 456 \\
Asia & 23 & 2 & 455 \\
Europe & 24 & 2 & 235 \\
Latin America \& Caribbean & 27 & 4 & 189 \\
Middle East \& North Africa & 12 & 1 & 109 \\
Oceania & 9 & 2 & 35 \\
\hline Total & 143 & 62 & 1479 \\
\hline
\end{tabular}

Source: authors' calculation based on [54].

Second, the World Bank's current subsector categorization was simplified and clarified since there are too many energy-related subsectors, and the projects approved before 1990 used different subsector names. Furthermore, some subsectors, such as the Power and the Other Energy and Extractives, have overly general names that make their objectives ambiguous. In this study, the current subsectors were rearranged depending on the similarity of purposes and were consequently grouped into six new subsectors: Fossil Fuels; NonHydro Renewable Energy (NHRE); Hydro; Transmission and Distribution; Institutional Reform and Capacity Building; and Non-Power Sector Energy Efficiency (Figure 3). The majority of subsectors fit into the new categories based on their names: from Oil and Gas and Non-Renewable Electricity Generation to Fossil Fuels, from Renewable Energy Solar, Wind, and Waste Management to NHRE, from Renewable Energy Hydro to Hydro, from Energy Transmission and Distribution and Information and Communications Technology (ICT) Services to Transmission and Distribution, and from Central and Local Government and Public Administration to Institutional Reforms and Capacity Building, and so on. If the name of a subsector did not clearly show the purpose, it was matched to the most relevant category based on the key components and objectives of the project mentioned in the project summary and project documents. For example, the Vanuatu Rural Electrification project approved in 2015 has the Other Energy and Extractives subsector. This subsector was renamed NHRE because the project report specified that the main component of this project was to increase the electricity access of off-grid households by subsidizing the retail cost of solar photovoltaic (PV) systems. On the other hand, for the Vietnam Clean Production and Energy Efficiency, the Other Energy and Extractives subsector was recategorized into Non-Power Sector Energy Efficiency since its main component was the effective delivery of the national energy efficiency program in key industrial sectors. 


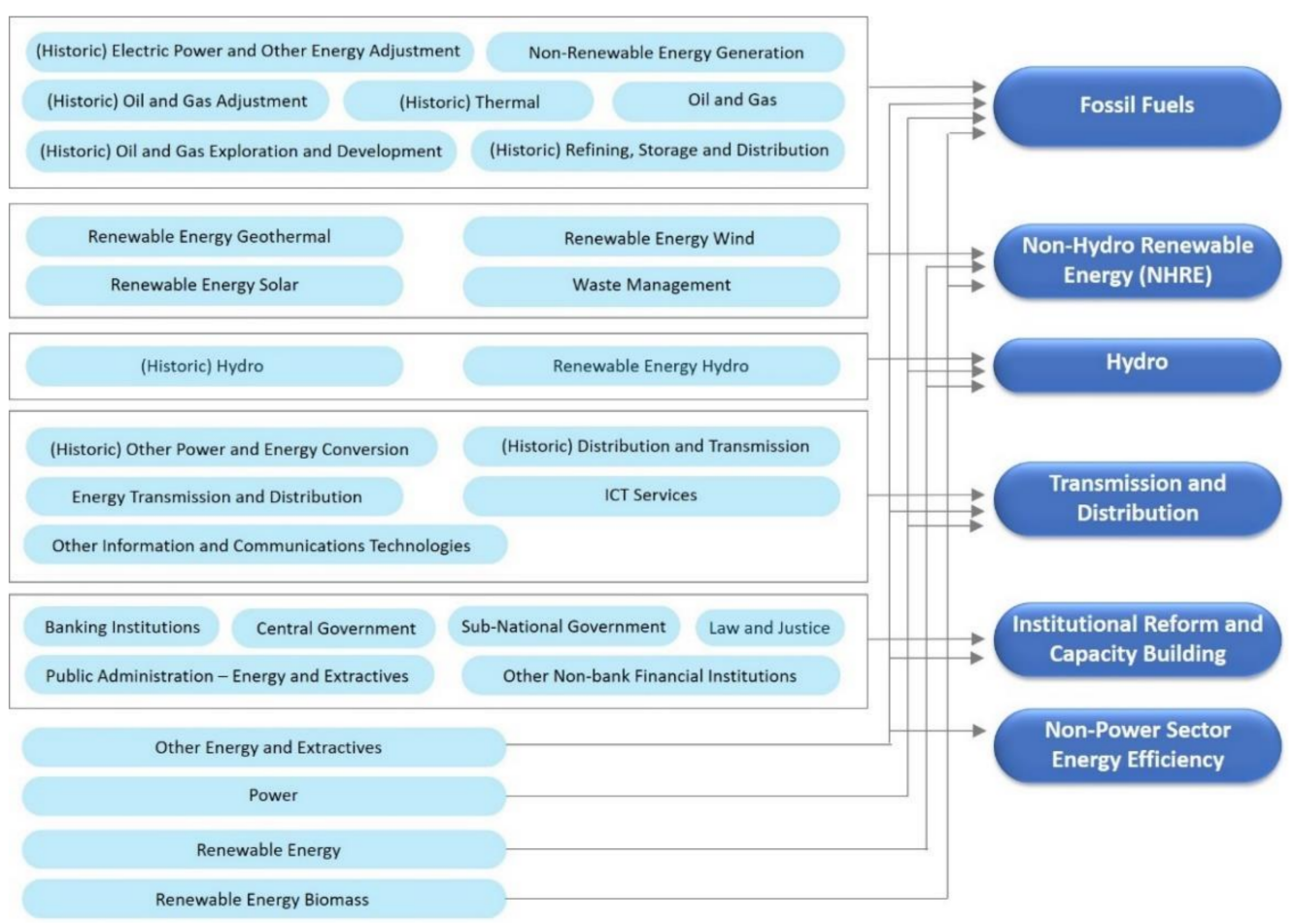

Figure 3. Recategorization of subsectors. Source: authors' elaboration based on [54].

One of the contentious issues with regard to the categorization of energy subsectors is whether hydropower can be placed in the same group as other renewable energy technologies [3]. Some scholars have separated hydropower and other renewable energy technologies as the role of hydropower in decarbonizing power systems would be diminished because of the limited potential capacity [25]. Moreover, while small and micro hydropower are generally considered renewable energies, including large hydropower in renewable energy sometimes arouses controversy due to the adverse effects on the environment and climate change that large hydropower plants may cause $[3,55,56]$. As the World Bank does not separate large hydropower and small and micro hydropower, this study regards hydropower and other renewable energy technologies as different subsectors: Hydro and NHRE. Solar, wind, geothermal, biomass, and waste energy were combined into one subsector (NHRE) because the subsector information is unconvincing in some cases. For example, some projects include all renewable energy technology subsectors, even though they focus on developing solar or wind energy. Moreover, many projects have only the Renewable Energy subsector instead of technology-specific subsectors.

Finally, annual investments for the respective new categories were calculated by aggregating investments in subsectors under each category. For investment data, commitment amounts were used because the final disbursements were available only for closed projects. The project summary indicates all subsectors related to the project and provides both the total cost and the share of the costs used for each subsector in percentage terms. Finances for certain subsectors were excluded in the recategorization, which means that the subsectors irrelevant to energy were dropped. For example, Kenya Off-grid Solar Access Project for Underserved Countries, approved in 2017, comprises five subsectors: Renewable Energy Solar (63\%); Water Supply (5\%); Renewable Energy Biomass (4\%); Public AdministrationEnergy and Extractives (15\%); and Energy Transmission and Distributions (13\%). The total commitment amount to this project, US\$150 million, was assigned to each new category based on its share: NHRE (67\%, US\$100.5 million); Institutional Reform and Capacity Building (15\%, US\$22.5 million); and Transmission and Distribution (13\%, US\$19.5 million). The commitment amount to the Water Supply subsector was excluded from energy finance because this sector was not regarded as an energy-related subsector during the recategorization process. As a result, the finance data remaining in the dataset can be regarded as 
the World Bank's investments used for energy-related activities only. In order to make the data comparable across time, nominal finance amounts were converted to real values (2019 US dollars) using the gross domestic product (GDP) deflator of the United States taken from the World Bank Open Data [57].

\section{Results}

\subsection{Trends of Total Energy Financing}

The cumulative investments that the World Bank committed to energy-related activities between 1985 and 2019 was US\$178.6 billion, accounting for 13.7\% of the total financial commitment to development projects (US\$1.3 trillion). Notwithstanding erratic fluctuations over the years, the annual energy finance and 5-year moving averages show that energy finance had declined from about US\$6 billion in the mid-1990s to US\$1.3 billion in 2003 - the lowest level throughout the last four decades (Figure 4). For the same period, the share of energy finance in total development finance was also reduced from approximately $17 \%$ to $5.1 \%$ (Figure 5). This decreasing trend resulted from the donors' keen interest in privatizing basic utilities in recipient countries and the expectation that private investment would play a greater role in constructing energy infrastructure $[29,58]$. However, as it has become clear that public financing is still critical to the development of energy infrastructure in developing countries, the World Bank has revitalized its commitment to the energy sector since the mid-2000s [29,58], with the launch of the Infrastructure Action Plan in 2003 and the Sustainable Infrastructure Action Plan in 2008. Hence, the volume and share of energy finance were reinstated to the former levels in the late 2000s and have hovered around US\$6-7 billion (5-year moving average) and 10-15\%, respectively, until the late 2010s (Figures 4 and 5).

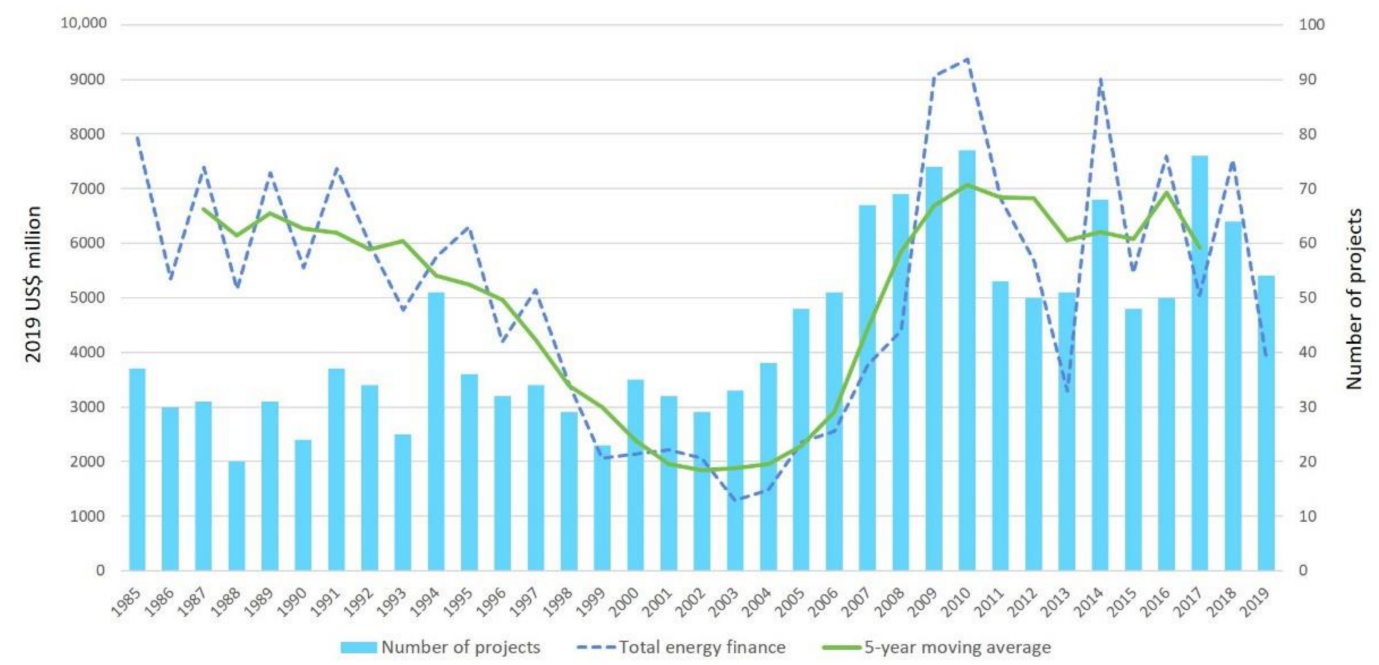

Figure 4. Total energy finance and number of energy-related projects (1985-2019). Source: authors' illustration based on [54]. 


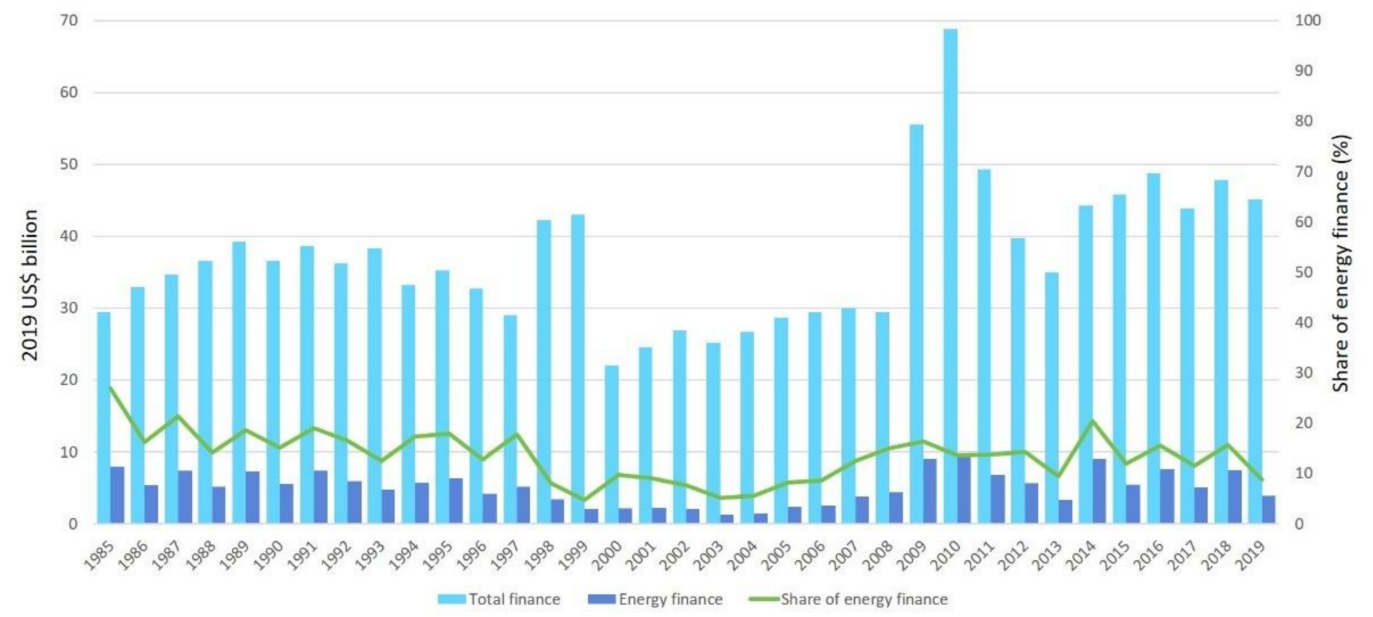

Figure 5. The World Bank's total development finance and energy finance (1985-2019). Source: authors' illustration based on [54].

On the other hand, the number of annual projects did not show a drastic variation between 1985 and 2002. Despite slight annual fluctuations, it remained at a constant level (approximately 25-35 projects per year) even during the periods when the total energy finance decreased. Then, it progressively increased in the mid-2000s and the late 2000s, and consequently, more than 70 projects were approved in 2009 and 2010. During the 2010s, approximately 57 projects were approved annually on average. The increased number of projects with a similar level of investment implies that investments per project declined. In fact, the average commitment amounts per project during the 1985-2000 and the 2001-2019 periods were respectively US $\$ 172.5$ million and US $\$ 86.5$ million.

\subsection{Regional Allocation of Energy Finance}

Asia has received the largest investments in energy activities over the last 35 years. Out of US $\$ 178.6$ billion of energy finance approved between 1985 and 2019, US\$82.3 billion (46.1\%) went to Asian countries, followed by US $\$ 35.5$ billion $(19.9 \%)$ in Sub-Saharan Africa, US\$28.6 billion (16.0\%) in Europe, US $\$ 18.2$ billion (10.2\%) in Latin America and the Caribbean, US $\$ 13.7$ billion (7.6\%) in the Middle East and North Africa (MENA) region, and US $\$ 0.3$ billion $(0.2 \%)$ in Oceania. However, careful scrutiny reveals more details about the trends in the regional allocation of energy finance over time.

Figure 6 shows that investments in energy-related projects in Sub-Saharan Africa and the MENA have markedly increased, whereas investments in Asia have decreased. Between 1985 and 2000, finance for Asia (US\$50.9 billion) comprised about $60 \%$ of the total investments due to a large number of projects on power plant construction and rural electrification. However, investments in Sub-Saharan Africa have significantly increased since the late 2000s as more and more rural electrification programs and regional transmission projects have been carried out in this region. Investments in the MENA have also increased, particularly since the mid-2010s, owing to approval for various projects to improve energy access, including renewable energy and transmission projects. Even though its dominant position has wavered due to the increase in energy finance in these two regions, Asia alsong with Sub-Saharan Africa are still major recipients. Asia and Sub-Saharan Africa received $32.9 \%$ (US $\$ 12.7$ billion) and 31.9\% (US $\$ 12.3$ billion) of total energy finance in the 2000s and $34.5 \%$ (US $\$ 18.7$ billion) and $31.9 \%$ (US $\$ 17.3$ billion) in the $2010 \mathrm{~s}$. 


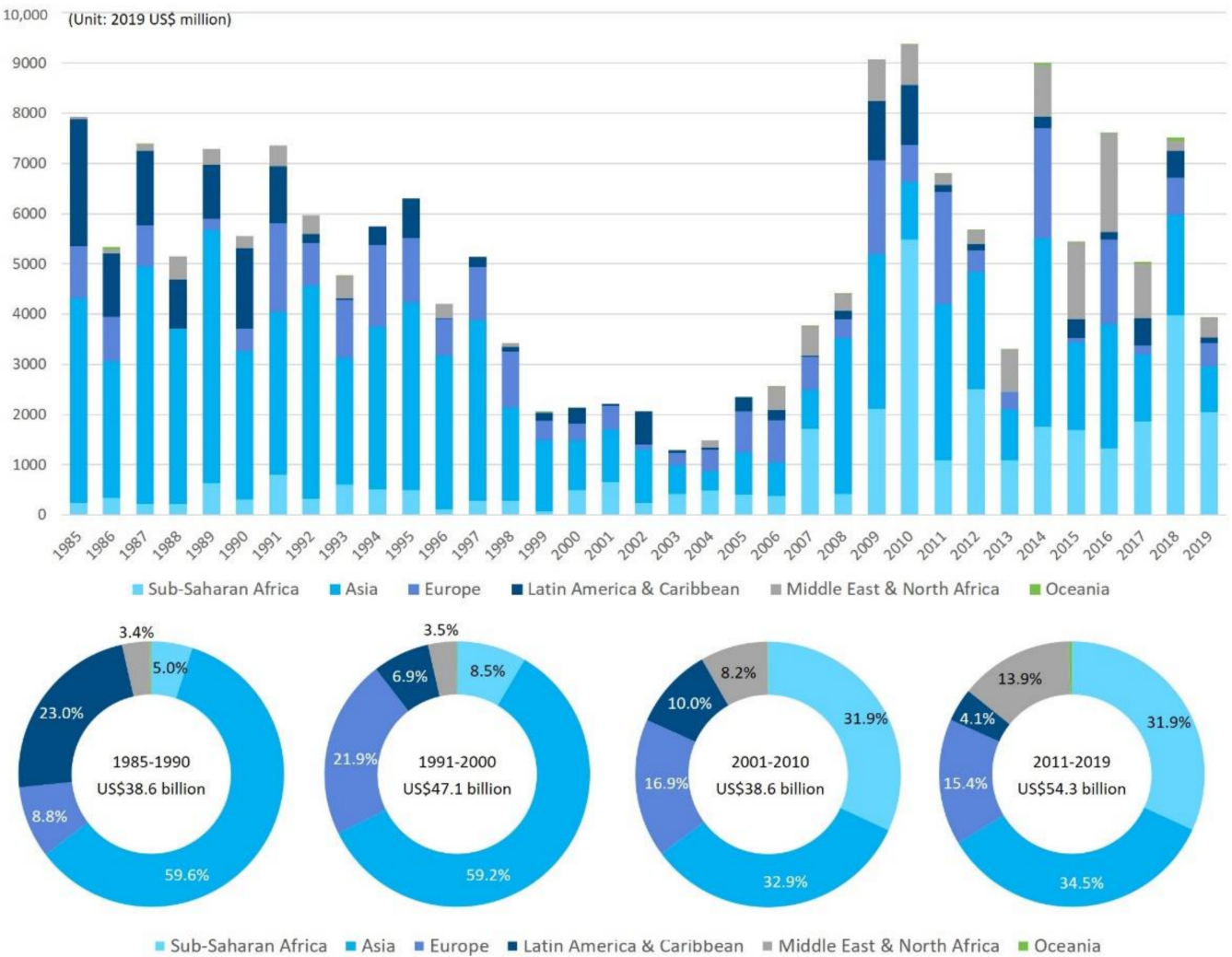

Figure 6. Regional allocation of energy finance (1985-2019). Source: authors' illustration based on [54].

Energy finance has also shown skewed distribution among developing countries. Table 3 lists the top 10 recipient countries by period. Although the World Bank's energy finance was allocated to 143 countries, more than half of the total energy finance was concentrated in only nine countries: India, China, Turkey, Indonesia, Pakistan, Egypt, Brazil, Vietnam, and Bangladesh. Although India obtained US\$27 billion, 43 countries received less than US\$100 million in the last 35 years. Major recipient countries by period correspond to patterns found in regional allocation. During 1985-1990, investments in Asia and Latin America and the Caribbean accounted for $82.6 \%$ of the total energy finance, and countries in these two regions were listed among the top 10 recipients. In the 1990s, the shares of Latin America and the Caribbean and Europe were reversed. Similarly, European countries (Russia, Poland, and Ukraine) were included in the top 10 recipients instead of Latin American countries (Brazil, Mexico, Argentina, and Colombia). In the 2000s and the 2010s, countries in Sub-Saharan Africa (South Africa, Nigeria, and Sub-Saharan African regional projects) and the MENA (Egypt and Iraq) received considerable funding with other Asian countries.

Additional trends in energy finance allocation at the country level are presented in Table 3. First, the primary recipient countries tended to be the most populous developing countries. All nine countries in the top 10 recipients belong to the top 20 countries with the world's largest population [59]. This implies that the number of people who stand to benefit from the project and the level of aid per capita of a country may be considerations for project approval by the World Bank. Second, the most impoverished countries were not the major beneficiaries of energy finance. Almost all countries listed in Table 3 are middle-income countries according to the World Bank's classification. Of the 52 least developed countries (LDCs) designated by the United Nations (UN) since 1971, only one country (Bangladesh) was included in the top 10 recipients. Finally, the concentration in the top recipient countries decreased. The share of investments in the top 10 recipient countries gradually decreased from $76.9 \%$ during $1985-1990$ to $67.3 \%$ in the $1990 \mathrm{~s}, 64.1 \%$ in 
the 2000s, and $53.0 \%$ in the 2010s. This decreasing trend was more apparent among the top three recipients. Between 1985 and 1990, the investments in the top three recipients reached almost half of the total energy finance, but it decreased to $21.9 \%$ in the 2010 s.

Table 3. Major recipient countries

\begin{tabular}{|c|c|c|c|c|c|c|}
\hline & Rank & 1985-2019 & 1985-1990 & 1991-2000 & 2001-2010 & 2011-2019 \\
\hline \multirow[t]{2}{*}{1} & Country & India & India & China & India & Africa (R) ${ }^{1}$ \\
\hline & Investments (US\$ million) & $27,022(15.1 \%)$ & $12,008(31.1 \%)$ & $9402(20.0 \%)$ & $5245(13.6 \%)$ & $4497(8.3 \%)$ \\
\hline \multirow[t]{2}{*}{2} & Country & China & Brazil & India & South Africa & Egypt \\
\hline & Investments (US\$ million) & $14,509(8.1 \%)$ & $3630(9.4 \%)$ & $6301(13.4 \%)$ & $4394(11.4 \%)$ & $3793(7.0 \%)$ \\
\hline \multirow[t]{2}{*}{3} & Country & Turkey & Indonesia & Russia & Turkey & Pakistan \\
\hline & Investments (US\$ million) & $10,170(5.7 \%)$ & $2513(6.5 \%)$ & $3683(7.8 \%)$ & $3798(9.9 \%)$ & $3581(6.6 \%)$ \\
\hline \multirow[t]{2}{*}{4} & Country & Indonesia & Pakistan & Indonesia & Vietnam & India \\
\hline & Investments (US\$ million) & 9107 (5.1\%) & $2358(6.1 \%)$ & $3132(6.6 \%)$ & $2039(5.3 \%)$ & $3470(6.4 \%)$ \\
\hline \multirow[t]{2}{*}{5} & Country & Pakistan & China & Pakistan & Egypt & Turkey \\
\hline & Investments (US\$ million) & $8451(4.7 \%)$ & $2137(5.5 \%)$ & $1992(4.2 \%)$ & $1968(5.1 \%)$ & $3085(5.7 \%)$ \\
\hline \multirow[t]{2}{*}{6} & Country & Egypt & Turkey & Thailand & China & Indonesia \\
\hline & Investments (US\$ million) & $6573(3.7 \%)$ & $1912(4.9 \%)$ & $1969(4.2 \%)$ & $1692(4.4 \%)$ & $2616(4.8 \%)$ \\
\hline \multirow[t]{2}{*}{7} & Country & Brazil & Mexico & Philippines & Mexico & Bangladesh \\
\hline & Investments (US\$ million) & $6388(3.6 \%)$ & $1637(4.2 \%)$ & $1463(3.1 \%)$ & $1570(4.1 \%)$ & $2266(4.2 \%)$ \\
\hline \multirow[t]{2}{*}{8} & Country & Africa $(\mathrm{R})^{1}$ & Argentina & Turkey & Brazil & Vietnam \\
\hline & Investments (US\$ million) & $5917(3.3 \%)$ & $1423(3.7 \%)$ & $1374(2.9 \%)$ & $1459(3.8 \%)$ & $2186(4.0 \%)$ \\
\hline \multirow[t]{2}{*}{9} & Country & Vietnam & Bangladesh & Poland & Africa $(R)^{1}$ & Iraq \\
\hline & Investments (US\$ million) & $5288(3.0 \%)$ & $1193(3.1 \%)$ & $1307(2.8 \%)$ & $1420(3.7 \%)$ & $1646(3.0 \%)$ \\
\hline \multirow[t]{2}{*}{10} & Country & Bangladesh & Colombia & Ukraine & Nigeria & Nigeria \\
\hline & Investments (US\$ million) & $5257(2.9 \%)$ & $943(2.4 \%)$ & $1086(2.3 \%)$ & $1098(2.8 \%)$ & $1627(3.0 \%)$ \\
\hline
\end{tabular}

${ }^{1}$ Regional projects for Sub-Saharan African countries. Source: authors' calculation based on [54].

\subsection{Energy Financing by Sector}

Figure 7 illustrates the World Bank's investments in various energy sectors between 1985 and 2019. Fossil Fuels took the lion's share (34.8\%) with a total of US\$62.1 billion, followed by Transmission and Distribution (US $\$ 53.3$ billion, $29.8 \%$ ), Hydro (US $\$ 22.3$ billion, $12.5 \%$ ), Institutional Reform and Capacity Building (US $\$ 18.1$ billion, 10.1\%), NHRE (US $\$ 16.7$ billion, 9.4\%), and Non-Power Sector Energy Efficiency (US\$6.1 billion, 3.4\%). However, these shares changed over time and varied regionally (Table 4).

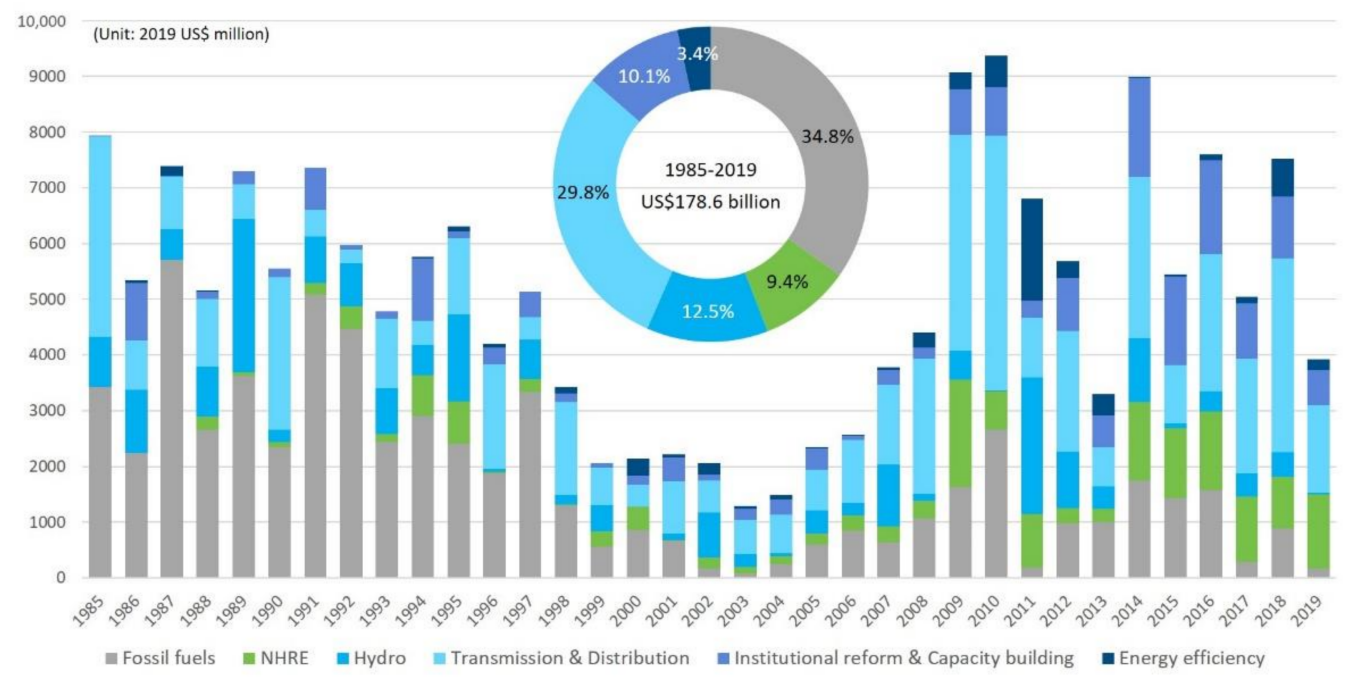

Figure 7. Sector-specific energy finance (1985-2019). Source: authors' illustration based on [54]. 
Table 4. Sector-specific energy finance by period and region (unit: 2019 US\$ million).

\begin{tabular}{|c|c|c|c|c|c|c|}
\hline & Fossil Fuels & NHRE & Hydro & $\begin{array}{l}\text { Transmission } \\
\text { \& Distribution }\end{array}$ & $\begin{array}{l}\text { Institutional Reform } \\
\text { \& Capacity Building }\end{array}$ & $\begin{array}{l}\text { Energy } \\
\text { Efficiency }\end{array}$ \\
\hline \multicolumn{7}{|l|}{ Period (annual average) ${ }^{1}$} \\
\hline $1985-1990$ & $3335(51.8 \%)$ & $61(1.0 \%)$ & $1080(16.8 \%)$ & $1667(25.9 \%)$ & $256(4.0 \%)$ & $43(0.7 \%)$ \\
\hline 1991-2000 & $2525(53.6 \%)$ & $320(6.8 \%)$ & $591(12.5 \%)$ & $882(18.7 \%)$ & $335(7.1 \%)$ & $60(1.3 \%)$ \\
\hline $2001-2010$ & $860(22.3 \%)$ & $417(10.8 \%)$ & $358(9.3 \%)$ & $1702(44.1 \%)$ & $360(9.3 \%)$ & $159(4.1 \%)$ \\
\hline 2011-2019 & $919(15.2 \%)$ & $996(16.5 \%)$ & $705(11.7 \%)$ & $1939(32.1 \%)$ & $1068(17.7 \%)$ & $407(6.8 \%)$ \\
\hline \multicolumn{7}{|l|}{ Region (total) } \\
\hline Sub-Saharan Africa & $9020(25.4 \%)$ & $4050(11.4 \%)$ & 3267 (9.2\%) & $14,681(41.3 \%)$ & $4465(12.6 \%)$ & $67(0.2 \%)$ \\
\hline Asia & $30,318(36.8 \%)$ & $6407(7.8 \%)$ & $13,466(16.4 \%)$ & $24,850(30.2 \%)$ & $5148(6.3 \%)$ & $2138(2.6 \%)$ \\
\hline Europe & $13,506(47.3 \%)$ & $1703(6.0 \%)$ & $2614(9.1 \%)$ & $5392(18.9 \%)$ & $2385(8.3 \%)$ & $2978(10.4 \%)$ \\
\hline Latin America \& Caribbean & $3721(20.4 \%)$ & $2327(12.8 \%)$ & $2679(14.7 \%)$ & $6310(34.6 \%)$ & $2333(12.8 \%)$ & $861(4.7 \%)$ \\
\hline Middle East \& North Africa & $5517(40.4 \%)$ & $2156(15.8 \%)$ & $175(1.3 \%)$ & $2015(14.8 \%)$ & $3715(27.2 \%)$ & $73(0.5 \%)$ \\
\hline Oceania & $44(14.1 \%)$ & $66(21.0 \%)$ & $106(33.6 \%)$ & $43(13.8 \%)$ & $55(17.5 \%)$ & 0 \\
\hline
\end{tabular}

${ }^{1}$ Annual average as presented as the number of years for each period is different. Source: authors' calculation based on [54].

The fossil fuel sector remains the largest beneficiary due to the huge investments made until the 1990s. However, it has experienced a drastic decrease in funding commitments since the early 2000s in terms of both financed amounts and percentage shares relative to total energy finance. The annual average investments in fossil fuels decreased from US\$3.3 billion during the period 1985-1990 to US\$0.9 billion during the period 2011-2019, and the share also contracted from $51.8 \%$ to $15.2 \%$ between the same period. Notably, the investments in the 1990s (US\$2.5 billion) fell by approximately two-thirds in the 2000s (US\$0.9 billion), and the share was more than halved.

The decreasing trends are found in Asia, Sub-Saharan Africa, and Latin America and the Caribbean (Figure 8). In Asia, fossil fuels received US\$2.5 billion per year (64.6\%) between 1985 and 1990, but the investments were reduced to US\$1.3 billion per year (46.0\%) in the 1990s and then to US\$136 million per year in the 2000s and the 2010s. The annual average investments were almost the same in the 2000s and the 2010s, but the share fell from $10.8 \%$ to $6.6 \%$. In Sub-Saharan Africa and Latin America and the Caribbean, the share of investments in fossil fuels respectively increased from $44.3 \%$ and $20.1 \%$ for the $1985-1990$ period to $63.1 \%$ and $55.1 \%$ for the $1991-2000$ period, but decreased to $27.6 \%$ and $2.8 \%$ for the $2001-2010$ period and $13.0 \%$ and $0.9 \%$ for the $2011-2019$ period. On the other hand, the decreasing trend is unclear in Europe and the MENA. In the MENA region, the annual average and share of fossil fuel investments gradually increased until the 2000s. In the 2010s, the annual average investments increased from US\$209 million to US\$215 million, but the share contracted from $65.7 \%$ to $25.6 \%$. In Europe, the amount and percentage decreased from US\$319 million per year (56.4\%) for the 1985-1990 period to US\$164 million per year $(21.6 \%)$ in the 2000 s, but rebounded to US\$313 million per year $(33.7 \%)$ in the 2010s. Hence, energy finance in Europe and the MENA were heavily concentrated on fossil fuels (47.3\% and 40.4\%, respectively) between 1980 and 2019 (Table 4). 


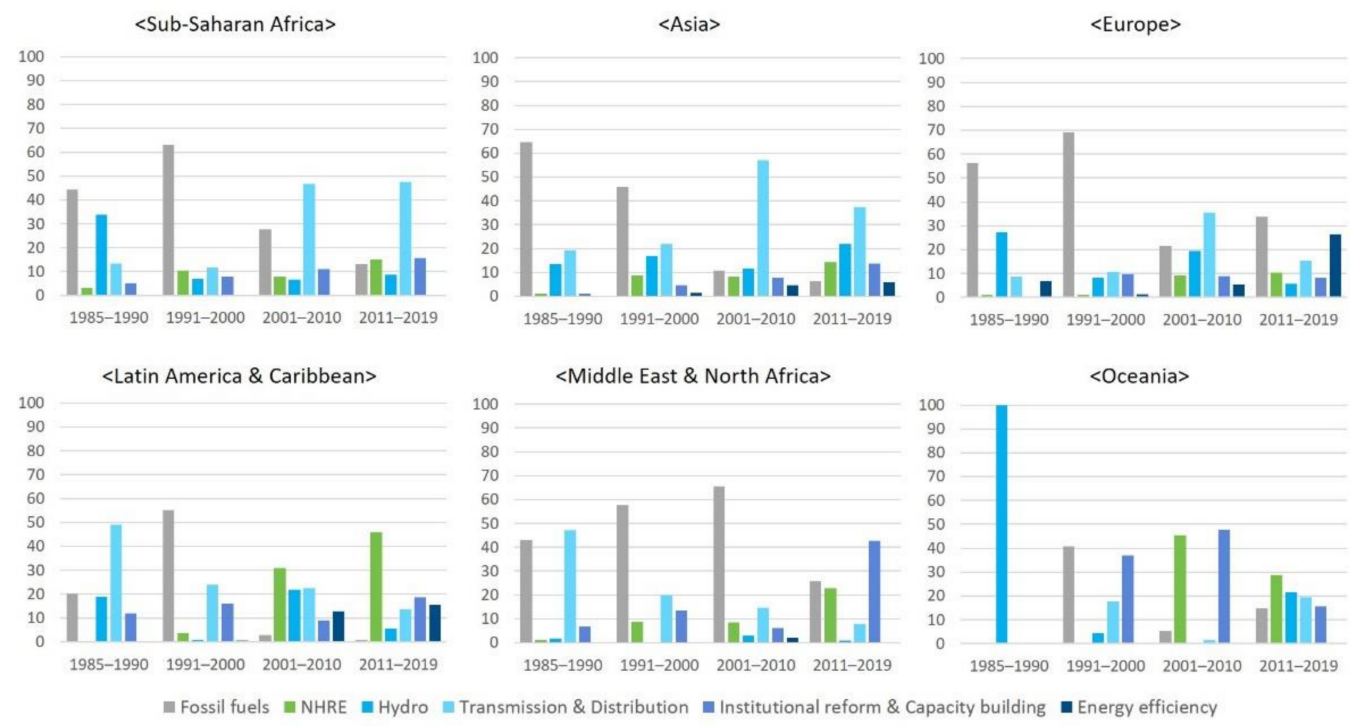

Figure 8. Share of each sector in energy finance by region and period. Source: authors' illustration based on [54].

At the country level, the top five countries received nearly half of the total investment in fossil fuels (Table 5). India, China, and Indonesia together received US\$21.7 billion $(34.9 \%)$, and most of which went to various thermal power projects implemented in the 1980s and 1990s. The large investments in Russia were attributable to support for the coal and oil sectors in the 1990s. The projects included the following components: restructuring and coal business, planning of sustainable coal production, rehabilitation and drilling of oil wells, construction of refineries, and replacement of oil production flow lines. While the other four countries were major beneficiaries in the 1980s and the 1990s, Egypt received considerable investments in fossil fuel projects more recently, which included the construction of thermal power plants and combined-cycle gas turbine power plants, and household natural gas connection projects in the 2000s and the 2010s.

Table 5. Major recipient countries of sector-specific finance for fossil fuels and NHRE (1985-2019).

\begin{tabular}{|c|c|c|c|c|c|c|c|}
\hline & & Fossil Fuels & NHRE & Hydro & $\begin{array}{c}\text { Transmission \& } \\
\text { Distribution }\end{array}$ & $\begin{array}{l}\text { Institutional Reform } \\
\text { \& Capacity Building }\end{array}$ & $\begin{array}{c}\text { Energy } \\
\text { Efficiency }\end{array}$ \\
\hline \multirow[t]{2}{*}{1} & Country & India & Indonesia & China & India & Egypt & Poland \\
\hline & Investments (US\$ million) & $12,439(20.0 \%)$ & $1361(8.1 \%)$ & $4360(19.5 \%)$ & $8484(15.9 \%)$ & $1777(9.8 \%)$ & $1308(21.4 \%)$ \\
\hline \multirow[t]{2}{*}{2} & Country & China & India & India & Africa $(\mathrm{R})^{1}$ & Pakistan & China \\
\hline & Investments (US\$ million) & $6211(10.0 \%)$ & $1312(7.9 \%)$ & $3716(16.7 \%)$ & $3796(7.1 \%)$ & $1773(9.8 \%)$ & $958(15.7 \%)$ \\
\hline \multirow[t]{2}{*}{3} & Country & Egypt & Turkey & Pakistan & Vietnam & Turkey & Mexico \\
\hline & Investments (US\$ million) & $4349(7.0 \%)$ & $1306(7.8 \%)$ & $2559(11.5 \%)$ & $2840(5.3 \%)$ & $1318(7.3 \%)$ & $623(10.2 \%)$ \\
\hline \multirow[t]{2}{*}{4} & Country & Russia & Mexico & Turkey & Brazil & Brazil & Turkey \\
\hline & Investments (US\$ million) & $3571(5.7 \%)$ & $1082(6.5 \%)$ & $1557(7.0 \%)$ & $2812(5.3 \%)$ & $1196(7.3 \%)$ & $515(10.2 \%)$ \\
\hline \multirow[t]{2}{*}{5} & Country & Indonesia & Philippines & Indonesia & Indonesia & Iraq & Vietnam \\
\hline & Investments (US\$ million) & $3021(4.9 \%)$ & $1079(6.5 \%)$ & $1436(6.4 \%)$ & $2790(5.2 \%)$ & $1135(6.3 \%)$ & $503(8.2 \%)$ \\
\hline
\end{tabular}

${ }^{1}$ Regional projects for Sub-Saharan African countries. Source: authors' calculation based on [54].

In contrast to fossil fuels, the NHRE sector shows a definite increasing trend in investments in terms of both the annual average and the share of investments. Between 1985 and 1990, investments in NHRE accounted for only 1\% (US\$61 million per year) of total energy finance, and $65.3 \%$ of NHRE funds went to geothermal projects in Kenya and the Philippines. As a result of an increased number of rural electrification projects relating to various NHRE technologies being approved since the mid-1990s, the commitment amount for NHRE and its corresponding percentage share increased to US\$320 million per year $(6.8 \%)$ in the 1990 s, to US\$417 million (10.8\%) in the 2000s, and finally to US\$996 million per year (16.5\%) in the 2010 s (Table 4 ). In particular, the investments in the 2010 s 
more than doubled compared to the previous 10 years, and surpassed investments in fossil fuels. Furthermore, more than US\$1 billion has been committed to the NHRE sector every year since 2014, except for 2018 (Figure 7).

Increasing trends were generally found in all regions (Figure 8). In Sub-Saharan Africa, the average annual investment rapidly increased despite a slight decrease in the percentage share in the 2000s-from US\$10 million (3.2\%) during the period 1985-1990 to US\$42 million $(10.4 \%)$ in the 1990 s, to US\$97 million $(7.9 \%)$ in the $2000 \mathrm{~s}$, and to US $\$ 2.9$ billion $(15.0 \%)$ in the 2010s. In Europe and Latin America and the Caribbean, sharp increases in the 2000s are remarkable. The annual average investments in NHRE in these two regions increased from US\$9.3 million and US\$12 million in the 1990s to US\$71 million and US\$119 million in the 2000s, respectively. The share also expanded from $0.9 \%$ and $3.7 \%$ to $9.3 \%$ and $31.0 \%$, respectively, during the same period. These increases resulted from approval for large renewable projects, including solar PV, solar thermal, and wind power, in Turkey, Mexico, and Argentina. On the other hand, Asia and the MENA experienced significant increases between the 2000s and the 2010s, from US\$102 million (8.1\%) to US\$300 million (14.4\%), and from US\$27 million (8.5\%) to US\$192 million (22.9\%). In particular, several rounds of funding for the Noor Solar Power Project in Morocco led to the rise in the NHRE finance for the MENA. In Oceania, although the share of NHRE finance was reduced from $45.3 \%$ to $28.8 \%$ between the 2000 s and 2010 s, the annual average increased from US $\$ 1.1$ million to US\$6.1 million due to the approval of regional-level sustainable energy project for the Pacific Islands, and renewable energy projects in Kiribati, Micronesia, Solomon Islands, Tuvalu, and Vanuatu.

At the country level, Indonesia, India, and Turkey respectively received approximate $8 \%$ of investments in NHRE, and Mexico and the Philippines accounted for $6.5 \%$ each (Table 5). Key projects, to which large amounts of finance were allocated, included several geothermal projects in Indonesia and the Philippines between 1988 and 2017, rural electrification projects in Indonesia in the 1990s, and various renewable energy projects in India, Turkey, and Mexico in the 2000s and the 2010s.

Investments in hydropower, another renewable energy source, gradually decreased from US\$1.1 billion per year (16.8\%) during the period 1985-1990 to US\$358 million per year (9.3\%) during 2001-2010, but spiked to 705 million (11.7\%) in the 2010s (Table 4). This increase was due mainly to the approval of large hydropower projects in Asia, such as Dasu hydropower project and Tarbela hydropower extension in Pakistan, Upper Cisokan pumped storage power project in Indonesia, Vishnugad Pipalkoti hydroelectric project in India, Trung Son hydropower project in Vietnam, and Nurek hydropower rehabilitation project in Tajikistan. Hydropower has an exceptionally high share $(33.6 \%)$ in Oceania due to the hydropower projects in Papua New Guinea, Samoa, and the Solomon Islands. Investments in China, India, Pakistan, Turkey, and Indonesia account for more than $60 \%$ of the total investments in the hydropower sector (Table 5). For China, major investments in hydroelectric power plants were made in the 1980s and the 1990s, and smaller investments continued in the 2000s and the 2010s. While India, Turkey, and Indonesia were the primary recipients between 1985 and 2011, Pakistan emerged as the largest recipient in the 2010s. Between 2012 and 2016, US\$1.8 billion was committed to hydropower projects in Pakistan, which accounted for $60.6 \%$ of total hydropower investments during the same period, and $28.7 \%$ in the 2010 s.

Power transmission and distribution projects, including building new power grids, maintaining existing grids, and upgrading electricity network systems with ICT, were other essential activities in which the World Bank continued to make considerable investments. This sector is vital for increasing energy access in developing countries with electricity generation projects. As shown in Table 4, annual average investments in this sector almost halved during the 1991-2000 period, compared to the previous period, but were recovered to a similar level in the 2000s. Furthermore, it comprised the highest share in energy finance in the 2000s (US\$1.7 billion per year, 44.1\%) and the 2010s (US\$1.9 billion per year, 32.1\%). 
Between 1985 and 2019, support for this sector was prominent, particularly in SubSaharan Africa (41.3\%), Latin America and the Caribbean (34.6\%), and Asia (30.2\%). However, investments by period show differences among these regions. While the investments in transmission and distribution tend to decrease in Latin America and the Caribbean, they show an increasing trend in Sub-Saharan Africa (Figure 8). For Latin America and the Caribbean, US $\$ 727$ million (49.0\%) was annually invested in supporting large-scale power transmission and distribution projects in Argentina, Brazil, Colombia, Guatemala, and Mexico during the 1986-1990 period, but the investments reduced by approximately $90 \%$ in the 1990s and to US\$34 million per year (13.7\%) in the 2010s. By contrast, the annual average investments in transmission and distribution in Sub-Saharan Africa increased from US\$43 million (13.4\%) during the 1985-1990 period to 575 million (46.7\%) in the 2000 s, reaching US\$913 million (47.5\%) in the 2010s. Although numerous country-level projects in Africa had been supported, it was the various regional projects to expand, connect, and reinforce power grids across borders that mainly led to this rise. These projects include Tanzania-Zambia Transmission Interconnector Project, North Core Regional Power Interconnector Project, Southern Africa Power Market Project, and Eastern Electricity Highway Project. On the other hand, investments in Asia have been relatively stable in terms of amounts despite fluctuations in the share: US\$745 million per year $(19.4 \%)$ during the $1985-1990$ period, US\$615 million per year $(22.0 \%)$ in the 1990 s, US $\$ 722$ million per year $(56.9 \%)$ in the 2000 s, and US $\$ 779$ million per year (37.5\%) in the 2010 s.

The largest recipient in transmission and distribution was India, receiving 15.9\% (US\$8.5 billion) of total investments in this sector (Table 5). Investments in India were continuously made between 1985 and 2019. Brazil was listed among the major recipients due to large investments made until the 1990s; however, the Sub-Saharan African region and Vietnam were on the list because of many projects funded in the 2000s and the 2010s.

Lastly, the World Bank expanded its commitment to institutional reform and capacity building projects and energy efficiency projects within the non-power sector. The former included various activities to reduce the investment risk and create an enabling environment, and the latter aimed to improve energy efficiency in industries, households, and buildings. Annual average investments and shares in these two sectors continually increased over this period. They reached US\$1.1 billion (17.7\%) and US $\$ 407$ million (6.8\%), respectively, during the 2011-2019 period, starting from US\$256 million (4.0\%) and US\$43 million ( $0.7 \%)$ during the period 1985-1990 (Table 4).

\section{Discussion}

Sector-specific energy finance shows that investments in NHRE have significantly increased and investments in fossil fuels have decreased over the last decades. While the share of investments in NHRE in the World Bank's total energy finance expanded from 1\% (1985-1990) to 16.5\% (2011-2019), the share of fossil fuels contracted from $51.8 \%$ (1985-1990) to $15.2 \%$ (2011-2019). Furthermore, the share of fossil fuels and NHRE in energy finance for each country has changed over time. In the 1990s, fossil fuels accounted for more than $50 \%$ of energy finance in 50 countries, more than $75 \%$ of energy finance in 35 countries, and $100 \%$ in 12 countries, including Algeria, Egypt, Malaysia, Nicaragua, Nigeria, Serbia, and Turkmenistan. However, countries where fossil fuels accounted for more than 50\% of energy finance in the 2010s were only six: Chad, Ghana, Guyana, Mauritania, Papua New Guinea, and Ukraine. On the other hand, the share of NHRE finance was more than $15 \%$ in 13 countries in the 1990s. However, in the 2010s, they increased to more than $50 \%$ in 25 countries and to more than $90 \%$ in 10 countries: Chile, Dominica, Gabon, Maldives, Mauritius, Nicaragua, Saint Lucia, South Africa, Seychelles, and Tuvalu.

These trends are in accordance with international consensus on the need to tackle climate change and increase renewable energy finance. Figure 9 suggests that anecdotal correlations may exist between increases in finance for NHRE and international climate change negotiations [14]. Increases in the share of investments in NHRE were brought about around the landmark decisions under the UNFCCC Conference of Parties (COP) to 
raise funds for climate change mitigation, although they were sometimes transient. The share of NHRE finance increased when the UNFCCC entered into force and after the Kyoto Protocol was adopted. Besides, the amounts and share of NHRE finance significantly increased from around the adoption of the Copenhagen Accord and the Paris Agreement, underlying the importance of climate finance for developing countries.

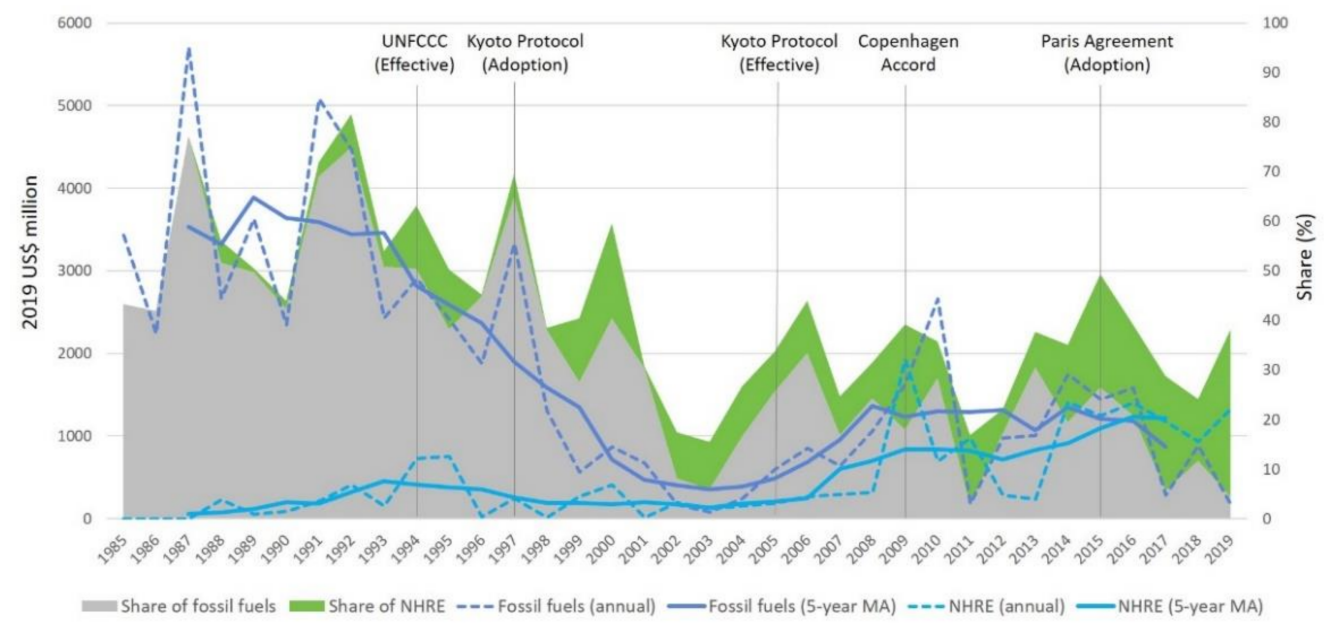

Figure 9. Finance for fossil fuels vs. NHRE (1985-2019). Source: authors' illustration based on [54].

Whenever international resolutions relating to climate finance were adopted, the World Bank expressed willingness to expand its commitments to renewable energy through relevant reports and announcements. For example, the Board of Executive Directors adopted a paper, Fuel for Thought: Environmental Strategy for the Energy Sector, which promised that the World Bank would make efforts to substitute conventional fuels with modern energy technologies by promoting renewable energy projects [26]. Moreover, World Bank Group Climate Change Action Plan 2016-2020 was published in 2016. It stated that the World Bank Group would scale up their investments in renewable energy so that $20 \mathrm{GW}$ could be added to renewable energy generation by 2020 [60]. As a result, five-year moving average amounts of NHRE exceeded fossil fuels in 2016 for the first time, and annual investments in NHRE have surpassed investments in fossil fuels every year since 2017. Therefore, it can be concluded that the allocation of priorities of the World Bank's energy finance has shifted from supporting fossil fuels to promoting renewable energy, and the World Bank is following the right path to stimulate energy transition in developing countries, overall.

Despite the positive effects of international energy aid recently reported [61-63], it is still difficult to assert that an increase in NHRE investment of the World Bank has played a significant role in energy transition and GHG emissions reduction in developing countries because there are many variables that impact them. Given that most developing countries are experiencing rapid economic growth, GHG emissions associated with their economic activities may outweigh those reduced by renewable energy generation. However, Table 6 suggests that positive correlations between the MDBs' renewable energy investments and energy transitions in developing countries could exist. The table presents the respective correlation coefficients between the World Bank's NHRE investment for a country between 2009 and 2018, increase in NHRE capacity and electricity output, and increase in $\mathrm{CO}_{2}$ emissions during the same time. While insignificant in upper-middle-income countries, the correlations were significant in lower-income countries. However, the World Bank's NHRE finance does not correlate with $\mathrm{CO}_{2}$ emissions, which implies other critical emission sources still exist. Although a more rigorous assessment is necessary for a thorough discussion on this issue, this simple correlation may support the argument that MDBs' finance can play an important role, at least in low-income developing countries. 
Table 6. Correlation coefficients between indicators.

\begin{tabular}{cccc}
\hline \multirow{2}{*}{ Region } & \multicolumn{2}{c}{ World Bank Investment in NHRE (2009-2018) } \\
\cline { 2 - 4 } & $\begin{array}{c}\text { Low-Income } \\
\text { Countries }\end{array}$ & $\begin{array}{c}\text { Lower-Middle-Income } \\
\text { Countries }\end{array}$ & $\begin{array}{c}\text { Upper-Middle-Income } \\
\text { Countries }\end{array}$ \\
\hline Increase in NHRE capacity & $0.8181^{* * *}$ & $0.4871^{* * *}$ & 0.1040 \\
Increase in NHRE electricity output & $0.7368^{* * *}$ & $0.5023^{* * *}$ & 0.1168 \\
Increase in $\mathrm{CO}_{2}$ emissions & 0.1506 & $0.5101^{* * *}$ & 0.0990 \\
\hline
\end{tabular}

*** $p$-value $<0.01$. Source: authors' calculation based on $[54,64,65]$.

The World Bank needs to address some limitations in raising the effectiveness of its NHRE investment. First, finance for NHRE is still insufficient despite its sharp increase over the last decade. Several reports have estimated the required funding for developing countries to achieve their renewable energy targets. For instance, at least US $\$ 16.1$ billion and US $\$ 25.8$ billion would be respectively, required annually for 28 Sub-Saharan African countries and 27 developing countries around the world to meet their renewable energy targets pledged to their NDCs $[13,18]$. More generally, US $\$ 40-45$ billion would be needed annually between 2021 and 2030 to provide developing countries with access to more sustainable energy, such as renewable energy and clean cooking [8]. According to Table 6, only US $\$ 1.2$ billion was annually committed to NHRE projects even during the 2016-2019 period when NHRE finance significantly increased. This means that a huge gap still exists between funding required and investments actually made in the NHRE sector, and international financial assistance for this sector needs to be scaled up, particularly for low-income developing countries where private investments are rarely available.

Next, although a shift in funding priorities toward renewable energy is observed, finance for fossil fuels is still quite substantial. Annual investments in fossil fuels were always greater than NHRE until 2015 in five-year moving average (Figure 9). The World Bank committed US $\$ 8.3$ billion to 83 projects having fossil fuel-related components in the 2010s. Particularly, US $\$ 2.9$ billion was committed to such projects even after the adoption of the Paris Agreement. Furthermore, the annual average investments and the shares increased during 2016-2019 in Europe and Oceania (Table 7). Such significant investments during this period were mainly attributable to the approval of several gas projects in Europe, such as Trans-Anatolian Natural Gas Pipeline Project (US\$849 million) to improve the security of Southeast Europe's energy supply, Ukraine Gas Supply Security Facility (US\$531 million) to support Naftogaz's gas purchase, and Turkey Gas Storage Expansion Project (US\$611 million).

Table 7. Investments in fossil fuels and NHRE by region and period (annual average) (unit: 2019 US\$ million).

\begin{tabular}{ccccccc}
\hline \multirow{2}{*}{ Region } & \multicolumn{2}{c}{$\begin{array}{c}\text { 1985-1993 } \\
\text { (Before the UNFCCC) }\end{array}$} & $\begin{array}{c}\text { 1994-2015 } \\
\text { (Under UNFCCC's Decisions) }\end{array}$ & \multicolumn{2}{c}{$\begin{array}{c}\text { 2016-2019 } \\
\text { (After Paris Agreement) }\end{array}$} \\
\cline { 2 - 7 } & Fossil Fuels & NHRE & Fossil Fuels & NHRE & Fossil Fuels & NHRE \\
\hline Sub-Saharan Africa & $218.3(53.5 \%)$ & $34.0(8.3 \%)$ & $305.9(29.7 \%)$ & $97.3(9.4 \%)$ & $81.8(3.5 \%)$ & $401.3(17.4 \%)$ \\
Asia & $2356.0(64.2 \%)$ & $70.6(1.9 \%)$ & $406.5(21.0 \%)$ & $194.9(2.5 \%)$ & $42.8(2.5 \%)$ & $371.3(22.1 \%)$ \\
Europe & $493.3(62.0 \%)$ & $3.3(0.4 \%)$ & $320.8(38.4 \%)$ & $58.8(7.0 \%)$ & $502.3(65.5 \%)$ & $95.0(12.4 \%)$ \\
Latin America \& Caribbean & $328.3(28.8 \%)$ & $2.0(0.2 \%)$ & $34.0(11.3 \%)$ & $71.5(23.8 \%)$ & $5.0(1.5 \%)$ & $184.0(54.5 \%)$ \\
Middle East \& North Africa & $158.1(55.8 \%)$ & $16.8(5.9 \%)$ & $169.3(50.0 \%)$ & $64.2(18.9 \%)$ & $92.5(10.2 \%)$ & $148.0(16.4 \%)$ \\
Oceania & $0.8(8.9 \%)$ & 0 & $0.5(9.3 \%)$ & $1.8(36.8 \%)$ & $6.8(21.9 \%)$ & $6.5(21.2 \%)$ \\
\hline Total & $3554.8(56.4 \%)$ & $126.6(2.0 \%)$ & $1236.8(27.8 \%)$ & $488.5(11.0 \%)$ & $730.8(12.1 \%)$ & $1205.8(20.0 \%)$ \\
\hline
\end{tabular}

Source: authors' calculation based on [54].

Some discouraging statistics have been presented in the recent reports. The $\mathrm{CO}_{2}$ emissions of the power sector in developing countries increased by 20\% between 2012 and 2019 because demand had been growing rapidly, with coal-fired power plants playing a 
critical role in electricity generation in this regard. Developing countries constructed 691 GW of coal-fired power plants during 2010-2019, making coal account for $44 \%$ of their electricity generation [66]. Besides, aggregated investments made in 2018 in 20 high-impact developing countries, including Bangladesh, Ethiopia, India, Indonesia, Kenya, Pakistan, Tanzania, and Vietnam, showed that investments in fossil fuels took the largest share and finance for renewable energy declined for the first time since 2013 [67]. Fossil fuels are regarded as the cheapest and most reliable resource for bridging the electricity access gap in developing countries. Furthermore, resource-rich developing countries support the exploration, production and exportation of oil and gas to earn revenue. Under these circumstances, development finance for fossil fuels from MDBs may contribute to the expansion of fossil fuel use by functioning as a fossil fuel subsidy. Given that dependence on fossil fuels would exacerbate developing countries' energy insecurity and heighten vulnerability to climate change, the commitment of MDBs to fossil fuels should be reduced.

Finally, the World Bank's finance for NHRE has not been allocated to countries with the greatest need. Out of 28 countries whose electricity access rates were less than $50 \%$ in 2018, 26 countries were LDCs. Since most LDCs suffer from low income and face structural barriers that impede sustainable development, they inevitably need more external financial assistance to improve their energy access situation than middle-income developing countries that can attract more private investment. However, the primary beneficiaries of the World Bank's NHRE finance were relatively wealthy countries, such as Indonesia, India, Turkey, Mexico, and the Philippines. Out of US $\$ 16.7$ billion invested in the NHRE sector between 1985 and 2019, only US\$3.2 billion (19.3\%) was distributed to the LDCs (Figure 10). This is not surprising because emission mitigation projects in middle-income countries are regarded as more cost-effective [7]. A positive trend found in Figure 10 is that the amount and share of NHRE finance for the LDCs increased from the late 2000s. Supporting the NHRE sector in the LDCs can contribute to mitigating GHG emissions and providing universal access to energy. Moreover, Table 7 shows that the MDBs' role is more important in low-income countries. Therefore, financing for NHRE in the LDCs should be scaled up.

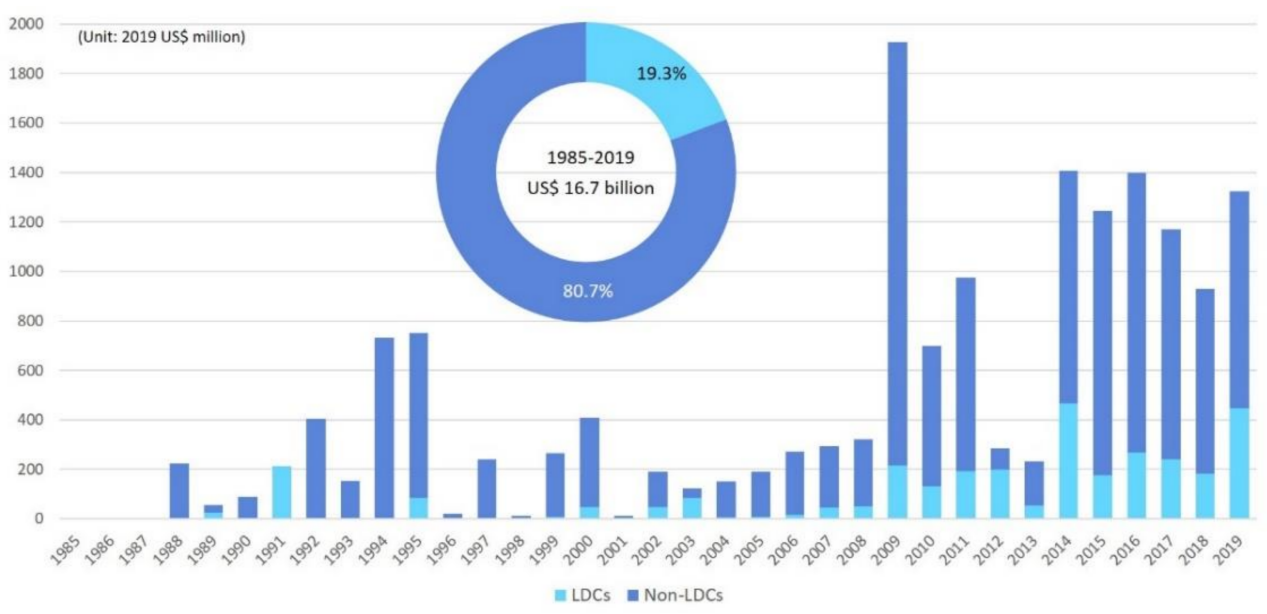

Figure 10. NHRE finance in LDCs and non-LDCs (1985-2019). Source: authors' illustration based on [54].

\section{Conclusions}

Energy transition in developing countries is necessary to achieving the global goal of limiting global temperature rise to well below $2{ }^{\circ} \mathrm{C}$. The demand for renewable energy finance in developing countries is expected to grow accordingly. The ODF from MDBs will remain a critical resource, especially for countries with difficulties attracting private investment. In this context, this study provides an updated and longer-term review of the 
World Bank's energy financing and discusses whether the financing has been on the right track toward supporting energy transition in developing countries.

Based on a comprehensive review, a series of notable trends was observed in this study. Most importantly, while the amounts and share of finance for fossil fuels have decreased, those of NHRE finance have substantially increased during the last 35 years. Specifically, the annual average amounts and proportions of investments in NHRE expanded from US\$61 million (1\%) for the 1985-1990 period to US\$996 million (16.5\%) for the 2011-2019 period, but that of fossil fuels contracted from US\$3.3 billion (51.8\%) to US\$919 million $(15.2 \%)$ for the same period. This confirms that the World Bank has been greening its energy finance by shifting allocation priorities toward promoting renewable energy. In addition to NHRE, the World Bank has also increased funding for power transmission and distribution projects to improve electricity access, institutional reform, and capacity building projects to enable long-term energy transition in the recipient countries.

However, financing for NHRE is still insufficient to meet the required funding, and fossil fuel projects are being supported due to the needs of developing countries. Reliance on fossil fuels in developing countries can accelerate climate change, which, in turn, would harm them more than developed countries. Furthermore, fossil fuels may not be as profitable as expected in the long term because of the gradual reduction in the global fossil fuel consumption and the consequent shrinking of the fossil fuel market [68]. As the support for fossil fuels would negatively impact developing countries in the long term, the MDBs' commitment to fossil fuels should be shifted to NHRE. In this regard, it is noteworthy that MDBs have pledged on upscaling climate finance to US $\$ 175$ billion by 2025 [50]. The World Bank has also promised to discontinue funding of upstream oil and gas projects after 2019 [51]. This study highlights that the increased financing for NHRE should be allocated to LDCs that require external financial assistance the most.

This study suggests further empirical analyses on the precise correlation between MDBs' energy finance and energy transition in developing countries. Even though simple correlation coefficients were provided in this study, further research based on a more robust evaluation methodology is required to enrich the understanding of the role of MDBs' energy finance. While several studies report that international energy and climate aid reduce recipient countries' carbon emissions and vulnerability to climate change by increasing renewable energy capacity [22,61-63], other studies assert otherwise by pointing out their insignificant impacts or conditional effects upon fossil fuel deposits and other financial incentives $[21,69,70]$. Therefore, it needs to investigate the net effect of the MDBs' energy investment on renewable energy generation and the use of fossil fuels in recipient countries, as well as the interaction between the MDBs' funding and other variables. If MDBs' funding does not have a net positive effect, then identifying the reason for such a shortfall would help raise the effectiveness of future energy finance.

Although MDBs' renewable energy finance has been insufficient in meeting the required financing for renewable energy targets in developing countries, private investments have stimulated rapid growth of renewable energy market in many countries. Therefore, mobilizing private investment is vital for accelerating the energy transition of developing countries. In addition to scaling up the MDBs' renewable energy finance, there is a need to create a conducive business environment with stronger incentives to attract more private investment needs to be created.

Author Contributions: Conceptualization, J.W.K. and J.-S.L.; methodology, J.W.K. and J.-S.L.; software, J.W.K.; validation, J.W.K. and J.-S.L.; formal analysis, J.W.K.; data curation, J.W.K.; writingoriginal draft preparation, J.W.K.; writing-review and editing, J.-S.L.; visualization, J.W.K.; supervision, J.-S.L. All authors have read and agreed to the published version of the manuscript.

Funding: This research received no external funding.

Institutional Review Board Statement: Not applicable.

Informed Consent Statement: Not applicable. 
Data Availability Statement: Publicly available datasets were analyzed in this study. This data can be found here: https://projects.worldbank.org (accessed on 31 August 2020); https://data. worldbank.org/indicator/NY.GDP.DEFL.ZS (accessed on 23 September 2020); https: / /irena.org/ Statistics/Download-Data (accessed on 3 April 2021); https:/ / edgar.jrc.ec.europa.eu/overview.php? v=booklet2020 (accessed on 3 April 2021).

Acknowledgments: The authors appreciate useful comments from the reviewers.

Conflicts of Interest: The authors declare no conflict of interest.

\section{References}

1. Climate Watch Historical GHG Emissions Data. Available online: https://www.climatewatchdata.org/ghg-emissions (accessed on 14 September 2020).

2. Christianson, G.; Lee, A.; Larsen, G.; Green, A. Financing the Energy Transition: Are World Bank, IFC, and ADB Energy Supply Investments Supporting a Low-Carbon Future? ; Working Paper; World Resources Institute (WRI): Washington, DC, USA, 2017; pp. 5-43.

3. Delina, L. Multilateral development banking in a fragmented climate system: Shifting priorities in energy finance at the Asian Development Bank. Int. Environ. Agreem. 2017, 17, 73-88. [CrossRef]

4. $\quad$ FS-UNEP Collaborating Centre; BNEF. Global Trends in Renewable Energy Investment 2019; Frankfurt School of Finance \& Management: Frankfurt, Germany, 2019; pp. 12-59.

5. Buchner, B.; Clark, A.; Falconer, A.; Macquarie, R.; Meattle, C.; Tolentino, R.; Wetherbee, C. Global Landscape of Climate Finance 2019; Climate Policy Initiative (CPI): San Francisco, CA, USA, 2019; pp. 8-32.

6. IRENA; CPI. Global Landscape of Renewable Energy Finance 2018; International Renewable Energy Agency (IRENA): Abu Dhabi, United Arab Emirates, 2018; pp. 17-38.

7. Bosetti, V.; Carraro, C.; Tavoni, M. Climate change mitigation strategies in fast-growing countries: The benefits of early action. Energy Econ. 2009, 31, 144-151. [CrossRef]

8. IEA. World Energy Outlook 2019; International Energy Agency (IEA): Paris, France, 2019; pp. 337-574.

9. Betzold, C. Fuelling the Pacific: Aid for renewable energy across Pacific Island countries. Renew. Sustain. Energy Rev. 2016, 58,311-318. [CrossRef]

10. Gujiba, H.; Thorne, S.; Mulugetta, Y.; Rai, K.; Sokona, Y. Financing low carbon energy access in Africa. Energy Policy 2012, 47,71-78. [CrossRef]

11. Keely, A.R. Renewable energy in Pacific Small Island Developing States: The role of international aid and the enabling environment from donor's perspectives. J. Clean. Prod. 2017, 146, 29-36. [CrossRef]

12. Niles, K.; Lloyd, B. Small Island Developing States (SIDS) \& energy aid: Impacts on the energy sector in the Caribbean and Pacific. Energy Sustain. Dev. 2013, 17, 521-530.

13. Muñoz Cabré, M.; Sokona, M.Y. Renewable Energy Investment in Africa and Nationally Determined Contributions (NDCs); Working Paper; Global Economic Governance Initiative (GEGI): Boston, MA, USA, 2016; pp. 1-27.

14. Atterídge, A.; Savvidou, G. Development aid for energy in Small Island Developing States. Energy Sustain. Soc. 2019, 9, 1-16. [CrossRef]

15. Schwerhoff, G.; Sy, M. Financing renewable energy in Africa-Key challenge of the sustainable development goals. Renew. Sustain. Energy Rev. 2017, 75, 393-401. [CrossRef]

16. Granoff, I.; Hogarth, J.R.; Miller, A. Nested barriers to low-carbon infrastructure investment. Nat. Clim. Chang. 2016, 6, 1065-1071. [CrossRef]

17. Kim, J.E. Sustainable energy transition in developing countries: The role of energy aid donors. Clim. Policy 2019, 19, 1-16. [CrossRef]

18. Senshaw, D.; Kim, J.W. Meeting conditional targets in nationally determined contributions of developing countries: Renewable energy targets and required investment of GGGI member and partner countries. Energy Policy 2018, 116, 433-443. [CrossRef]

19. Dornan, M.; Shah, K.U. Energy policy, aid, and the development of renewable energy resources in Small Island Developing States. Energy Policy 2016, 98, 759-767. [CrossRef]

20. Delina, L. Clean energy financing at Asian Development Bank. Energy Sustain. Dev. 2011, 15, 195-199. [CrossRef]

21. Kretschmer, B.; Hübler, M.; Nunnenklamp, P. Does foreign aid reduce energy and carbon intensities of developing economies? J. Int. Dev. 2013, 25, 67-91. [CrossRef]

22. Tirpak, D.; Adams, H. Bilateral and multilateral financial assistance for the energy sector of developing countries. Clim. Policy 2008, 8, 135-151. [CrossRef]

23. Ansari, M.; Alakwaa, G. The critical role of multilateral institutions in MENA's renewable sector. APICORP Energy Res. 2018, $3,1-3$.

24. Miyamoto, K.; Chiofalo, E. Official Development Finance for Infrastructure: With a Special Focus on Multilateral Development Banks; Working Paper; Organisation for Economic Cooperation and Development (OECD): Paris, France, 2016 ; pp. 6-7.

25. Steffen, B.; Schmidt, T.S. A quantitative analysis of 10 multilateral development banks' investment in conventional and renewable power-generation technologies from 2006 to 2015. Nat. Energy 2019, 4, 75-82. [CrossRef] 
26. Martinot, E. Renewable energy investment by the World Bank. Energy Policy 2001, 29, 689-699. [CrossRef]

27. OECD Creditor Reporting System (CRS) Database. Available online: https://stats.oecd.org/Index.aspx?DataSetCode=crs1\# (accessed on 5 October 2020).

28. Wright, H.; Holmes, I.; Barbe, R.; Hawkins, J. Greening Financial Flows: What Progress Has Been Made in the Development Banks? Briefing Paper; E3G: London, UK, 2017; pp. 1-14.

29. Barnes, D.F.; Singh, B.; Shi, X. Modernizing Energy Services for the Poor: A World Bank Investment Review-Fiscal 2000-08; The World Bank: Washington, DC, USA, 2010; pp. 1-15.

30. Razavi, H. Oil and gas financing by the World Bank. Energy Policy 1995, 23, 1001-1007. [CrossRef]

31. Bruggink, J. Energy Aid in Times of Climate Change: Designing Climate Compatible Development Strategies; Energy Research Centre of the Netherlands (ERC): Petten, The Netherlands, 2012; pp. 10-21.

32. Mendez, A.; Houghton, D.P. Sustainable banking: Multilateral development banks as norm entrepreneurs. Sustainability 2020, 12, 972. [CrossRef]

33. Ragosa, G.; Warren, P. Unpacking the determinants of cross-border private investment in renewable energy in developing countries. J. Clean. Prod. 2019, 235, 854-865. [CrossRef]

34. ADB; AfDB; EBRD; EIB; IDB; IFC; WB. Joint Report on MDB Climate Finance 2012; European Bank for Reconstruction and Development (EBRD): London, UK, 2013; pp. 8-11.

35. ADB; AfDB; EBRD; EIB; IDB; WBG. Joint Report on MDB Climate Finance 2013; European Investment Bank (EIB): Luxembourg, Luxembourg, 2014; pp. 11-14.

36. ADB; AfDB; EBRD; EIB; IDB; WBG. 2014 Joint Report on Multilateral Development Banks' Climate Finance; The World Bank: Washington, DC, USA, 2015; pp. 19-22.

37. ADB; AfDB; EBRD; EIB; IDB; WBG. 2015 Joint Report on Multilateral Development Banks' Climate Finance; Asian Development Bank (ADB): Manila, Philippines, 2016; pp. 22-25.

38. ADB; AfDB; EBRD; EIB; IDBG; WBG. 2016 Joint Report on Multilateral Development Banks' Climate Finance; EBRD: London, UK, 2017; pp. 15-16.

39. ADB; AfDB; EBRD; EIB; IDBG; IsDB; WBG. 2017 Joint Report on Multilateral Development Banks' Climate Finance; EBRD: London, UK, 2018; pp. 16-17.

40. ADB; AfDB; EBRD; EIB; IDBG; IsDB; WBG. 2018 Joint Report on Multilateral Development Banks' Climate Finance; EBRD: London, UK, 2019; pp. 19-21.

41. ADB; AfDB; AIB; EBRD; EIB; IDBG; IsDB; WBG. 2019 Joint Report on Multilateral Development Banks' Climate Finance; EBRD: London, UK, 2020; pp. 20-23.

42. BNEF. Climatescope 2020: Emerging Markets Cross-Border Clean Energy Investment. Available online: https://globalclimatescope.org/clean-energy-investments (accessed on 1 April 2021).

43. Baumli, K.; Jamasb, T. Assessing private investment in African renewable energy infrastructure: A multi-criteria decision analysis approach. Sustainability 2020, 12,9425. [CrossRef]

44. Griffith-Jones, S.; Ocampo, J.A.; Spratt, S. Financing Renewable Energy in Developing Countries: Mechanisms and Responsibilities; Overseas Development Institute (ODI): London, UK, 2012; pp. 8-23.

45. IRENA. Unlocking Renewable Energy Investment: The Role of Risk Mitigation and Structured Finance; IRENA: Abu Dhabi, United Arab Emirates, 2016; pp. 19-30.

46. Jankauskas, V.; Rudzkis, P.; Kanopka, A. Risk factors for stakeholders in renewable energy investments. Energetika 2014, 60, 113-124. [CrossRef]

47. ADB; AfDB; CDB; EBRD; IDBG; IFAD; IsDB; WBG. Multilateral Development Banks and Private Sector Engagement for Sustainable Development; Global Partnership for Effective Development Co-operation (GPEDC): New York, NY, USA, 2019 ; pp. 5-18.

48. Nelson, R.M. Multilateral Development Banks: Overview and Issues for Congress; Congressional Research Service (CRS): Washington, DC, USA, 2020; pp. 1-18.

49. ADB; AfDB; EBRD; EIB; IDB; WBG. Joint Statement by Multilateral Development Banks at Paris, COP21. 2015. pp. 1-3. Available online: https://www.eib.org/attachments/press/joint-mdb-statement-climate_nov-28_final.pdf (accessed on 10 November 2020).

50. ADB; AfDB; AIIB; EBRD; EIB; IDBG; IsDB; NDB; WBG. High Level MDB Statement. 2019. pp. 1-2. Available online: https: / / www.adb.org/sites/default/files/page/41117/climate-change-finance-joint-mdb-statement-2019-09-23.pdf (accessed on 10 November 2020).

51. World Bank. World Bank Group Announcements at One Planet Summit, Press Release, 12 December 2017. Available online: https: / /www.worldbank.org/en/news/press-release/2017/12/12/world-bank-group-announcements-at-one-planet-summit (accessed on 28 September 2020).

52. Pueyo, A. What constrains renewable energy investment in Sub-Saharan Africa? A comparison of Kenya and Ghana. World. Dev. 2018, 109, 85-100.

53. UNEP. Green Finance for Developing Countries: Needs, Concerns and Innovations; United Nations Environment Programme (UNEP): Nairobi, Kenya, 2016; pp. 15-18.

54. World Bank Projects \& Operations. Available online: https://projects.worldbank.org/ (accessed on 31 August 2020). 
55. Ferreira, J.H.; Camacho, J.R. Prospects of small hydropower technology. In Renewable Hydropower Technologies; Ismail, B.I., Ed.; InTech: Rijeka, Croatia, 2017; Chapter 2; pp. 7-23.

56. IRN. Twelve Reasons to Exclude Large Hydro from Renewables Initiatives; International Rivers Network (IRN): Berkeley, CA, USA, 2003; pp. 1-10.

57. World Bank Open Data-GDP Deflator. Available online: https://data.worldbank.org/indicator/NY.GDP.DEFL.ZS (accessed on 23 September 2020).

58. Bayliss, K.; McKinley, T. Providing basic utilities Africa in sub-Saharan: Why has privatization failed? Environ. Sci. Policy Sustain. Dev. 2007, 49, 26-32. [CrossRef]

59. World Bank Open Data-Total Population. Available online: https://data.worldbank.org/indicator/SP.POP.TOTL (accessed on 22 December 2020).

60. WBG. World Bank Group Climate Change Action Plan 2016-2020; International Bank for Reconstruction and Development (IBRD): Washington, DC, USA, 2016; pp. 33-39.

61. Scandurra, G.; Thomas, A.; Passaro, R.; Bencine, J.; Carfora, A. Does climate finance reduce vulnerability in Small Island Developing States? An empirical investigation. J. Clean. Prod. 2020, 256, 120330. [CrossRef]

62. Ikegami, M.; Wang, Z. Does energy aid reduce CO2 emission intensities in developing countries? J. Environ. Econ. Policy 2021. [CrossRef]

63. $\mathrm{Wu}, \mathrm{X}$; Pan, A.; She, Q. Direct and indirect effects of climate aid on carbon emissions in recipient countries. J. Clean. Prod. 2021, 290, 125204. [CrossRef]

64. IRENA Data \& Statistics. Available online: https://irena.org/Statistics/Download-Data (accessed on 3 April 2021).

65. EDGAR Emissions Database for Global Atmospheric Research. Available online: https://edgar.jrc.ec.europa.eu/overview.php? $\mathrm{V}=$ booklet2020 (accessed on 3 April 2021).

66. BNEF. Climatescope Emerging Markets Outlook 2020; Bloomberg New Energy Finance (BNEF): New York, NY, USA, 2020 ; pp. 1-31.

67. SEforALL; CPI. Energizing Finance: Understanding the Landscape 2020; Sustainable Energy for All (SEforALL): Vienna, Austria, 2020; pp. 8-33.

68. Cyst, J.; Manley, D.; Cecchinato, G. Unburnable wealth of nations. Financ. Dev. 2017, 54, 46-49.

69. Yang, S.; Park, S. The effects of renewable energy financial incentive policy and democratic governance on renewable energy aid effectiveness. Energy Policy 2020, 145, 111682. [CrossRef]

70. Mahalik, M.K.; Villanthenkodath, M.A.; Mallick, H.; Gupta, M. Assessing the effectiveness of total foreign aid and foreign energy aid inflows on environmental quality in India. Energy Policy 2021, 149, 112015. [CrossRef] 